\title{
Comparative environmental sustainability study of an improved sewage sludge treatment and sludge reuse system based on emergy analysis in China
}

\author{
Junxue Zhang ${ }^{1} \cdot$ Lin $\mathrm{Ma}^{2,3}$ \\ Received: 14 April 2020 / Accepted: 29 July 2021 / Published online: 6 August 2021 \\ (c) The Author(s) 2021
}

\begin{abstract}
As the significant residuals in the sewage treatment system, sludge treatment and reuse play a pivotal impact on the environmental sustainability study in China. In this paper, two sewage sludge treatment systems have been investigated, calculated, and analyzed, including the conventional treatment system (Scenario A) and improved reuse system (Scenario B), respectively. The results demonstrate that (1) Compared to Scenario A, Scenario B is a comprehensive system, which integrates a sewage sludge treatment system and a brick production system for sludge recycling. (2) After considering the brick system (scenario B), on the one hand, the sludge treatment capacity has been enhanced and raised sludge utilization; on the other hand, negative influences have also generated due to the non-renewable resources input and several outputs. (3) In Scenario A and Scenario B, the input resources part reflects the main impact (about 59.6\% in the entire emergy value). (4) In this new paper, the UEVs are $2.73 \mathrm{E}+11 \mathrm{sej} / \mathrm{kg}$ and $6.29 \mathrm{E}+11 \mathrm{sej} / \mathrm{kg}$ in Scenario A and Scenario B, respectively. (5) The emergy sustainability indexes (ESI) are 0.012292 and 0.00848 , which express the weak comprehensive effects in Scenario A and Scenario B. (6) Scenario B has a more extensive range of change than Scenario A because of the more resource input for the sensitivity analysis. Given the all discussions, there are two effective approaches to be used for perfecting environmental sustainability in the Scenario A system and Scenario B system.
\end{abstract}

Keywords Sewage sludge treatment and reuse $\cdot$ Emergy analysis $\cdot$ Indicators $\cdot$ Sustainability

\section{Introduction}

A mass of sewage discharge was performed in order to satisfy economic development demand in China. In 2015, a great deal of wastewater was produced (73.53 billion tons), including chemical oxygen demand (22.235 million tons) and $\mathrm{NH}_{3}-\mathrm{N}$ (2.299 million tons) (China Environmental Statistics Annual Report 2015). Therefore, lots of sewage sludge will generate after sewage discharge. On the one hand, vast quantities of mud are buried in landfills resulting in severe

Junxue Zhang

zhangjunxue2017@foxmail.com

1 School of Architecture, Southeast University, Nanjing 210096, China

2 Environmental School, China University of Geosciences, Wuhan 430070, China

3 State Key Laboratory of Biogeology and Environmental Geology, Wuhan, China environmental load for sustainable development in China (Kui and Boqiang 2019; Wenjun et al. 2019). On the other hand, a lot of resources were wasted, such as sewage sludge, but the sewage sludge can be reused as a recycling resources to reduce waste. Under such a circumstance, it is necessary to develop the improved sludge treatment and reuse system to enhance environmental sustainability in China.

Until now, several related sludge studies were executed by some researchers on the basis on disparate views. Plenty of scholars have investigated sewage sludge reuse directions, such as material angles (Yuchi et al. 2020; Zhi-Xiang et al. 2019), agricultural perspective (Mirko et al. 2019; Cassio et al. 2019; Bo et al. 2019), health effects (Choudri and Yassine 2019), the biological perspective (Patrick et al. 2019; Agata et al. 2019), land application (Liping et al. 2019), chemical angles (Xueya et al. 2019; Jialin et al. 2020), Urban field (Nozela et al. 2018), life cycle assessment (LCA) perspective (Raphael et al. 2018; Domagoj Nakic 2018), and systematic assessment framework (Ferrans et al. 2020). 
In addition, several shortcomings can be found in these studies, containing (1) The single views. There is only one or insufficient views to explain the sludge reuse process and results, which have inaccurate results. (2) Lack of consideration for natural resources. The negative effect will be generated for the sustainability of evaluated system. (3) Disparate sludge reuse subsystem proportion. The undifferentiated contribution degree will lead to a certain amount of error. (4) Be short of a unified platform, consisting of resources, energy, labor, and reuse subsystem. (5) Without pollutant emissions consideration simultaneously, such as waste gas. Based on the above five drawbacks, the results of the environmental sustainability evaluation are subject to mistakes for some extent.

Compared to these studies, the emergy approach can perfect the defects and it was brought up by odum (Odum 1996). Emergy method considers all inputs, including renewable energy, non-renewable resource, synthetic fuels labor, and pollutants, in order to complete environmental sustainability assessment on a comprehensive platform. Hence, it can be applied to different systems of of natural, artificial, and complex models and realize the assessment by a series of indices. On the basis of emergy method, lots of stuids have been conducted, involving sewage system evaluation (Junxue and Lin 2020), agricultural studies (XiaoHong et al. 2010, 2018), city assessments (Gengyuan et al. 2015; Brandon and Winfrey 2016), green building field (Shuai et al. 2017; Marc et al. 2016), production systems (Natalia et al. 2018; Johanna et al. 2001), national research (Sam et al. 2019), pollutant treatment (Ling et al. 2014), traffic range (Sadegh et al. 2020).

Specifically speaking, XiaoHong et al. (2010) have carried out relationship research between sustainability and sludge reuse in China. Based on the emergy method, XiaoHong et al. (2018) investigated sustainability through earthworm compositing technology in sewage sludge treatment (Xiaohong et al. 2018). In view of four different Scenarios in sewage sludge treatment systems, sustainability has been assessed using improved emergy indicators by Gengyuan et al. (2015) (Gengyuan et al. 2015). Taking wastewater treatment as an example, Brandon et al. (2016) assessed sustainability several on the basis of emergy approach in China (Brandon and Winfrey 2016). Shuai et al (2017) implemented emergy analysis in the sewage treatment factory, which involved a sludge treatment process (Shuai et al. 2017). The LCA-emergy method has been used in the wastewater treatment system, and the sludge waste products can be utilized in land application (Marc et al. 2016). Natalia et al. (2018) performed an emergy analysis for sustainability by using biosolids generated in a municipal wastewater treatment plant (Natalia et al. 2018). Emergy analysis of municipal wastewater treatment has been executed, and the electricity was generated by digestion of sewage sludge (Johanna et al. 2001). Via the in urban water systems, a holistic emergy analysis was carried out by Sam et al. (2019) (Sam et al. 2019). Ling et al. (2014) conducted some introductions about the method, indicator, and application in the wastewater treatment system on the basis of emergy method, including the sludge treatment process (Ling et al. 2014). According to the study of Sadegh et al. (2020), a sustainability evaluation of wastewater treatment plants has been surveyed based on Emergy-LCA method (Sadegh et al. 2020).

Three disadvantages can be displayed in Table 1, including (1) Lack of comprehensive sewage sludge treatment and reuse assessment system. By the statistics of research articles, the comprehensive sewage sludge reuse system emergy has not been considered in the system (shown in Table 1). (2) Old emergy baseline. Most of the articles applied the old energy baselines. (3) Partial emergy indexes. There are only the basic emergy indicators and lack of indicators of
Table 1 Comparisons of published papers using emergy in sludge reuse systems

\begin{tabular}{|c|c|c|c|c|c|c|}
\hline \multirow[t]{2}{*}{ No } & \multirow[t]{2}{*}{ References } & \multirow[t]{2}{*}{ Emergy baseline } & \multicolumn{3}{|c|}{ Sludge and emergy analysis } & \multirow[t]{2}{*}{ Country } \\
\hline & & & $\begin{array}{l}\text { Sludge } \\
\text { treatment }\end{array}$ & Single reuse & Second reuse & \\
\hline 1 & Johanna et al. (2001) & Old & $\checkmark$ & $x$ & $x$ & Sweden \\
\hline 2 & XiaoHong et al. (2010) & Old & $\checkmark$ & $\checkmark$ & $x$ & China \\
\hline 3 & Ling et al. (2014) & Old & $\checkmark$ & $x$ & $x$ & China \\
\hline 4 & Gengyuan et al. (2015) & Old & $\checkmark$ & $\checkmark$ & $x$ & China \\
\hline 5 & Brandon et al. (2016) & Old & $\checkmark$ & $x$ & $x$ & USA \\
\hline 6 & Marc et al. (2016) & Old & $\checkmark$ & $\checkmark$ & $x$ & USA \\
\hline 7 & Shuai et al. (2017) & Old & $\checkmark$ & $x$ & $x$ & China \\
\hline 8 & XiaoHong et al. (2018) & New & $\checkmark$ & $\checkmark$ & $x$ & China \\
\hline 9 & Natalia et al. (2018) & Old & $\checkmark$ & $\checkmark$ & $x$ & Colombia \\
\hline 10 & Sam et al. (2019) & New & $\checkmark$ & $x$ & $x$ & USA \\
\hline 11 & Sadegh et al. (2020) & None & $\checkmark$ & $x$ & $\times$ & Iran \\
\hline$\sim$ & This paper Now & New & $\checkmark$ & $\checkmark$ & $\checkmark$ & China \\
\hline
\end{tabular}

لو مدينة الملأ عبدالعزيز

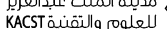


improvement. The above three disadvantages should be solved in sewage sludge treatment, and reuse system and these weaknesses support the completion of this article.

In this paper, two sewage sludge treatment systems are designed to assess sustainability, which have four contributions: (1) Taking entire views into account so as to evaluate sludge reuse process; (2) Building an improved and integral emergy indicators; (3) Computing two unit emergy values of different sludge reuse systems; (4) Raising the resolution strategies to improve negative results.

In the end, the structure of this paper is shown as follows. Part 1 is introduction. Part 2 demonstrates the data and method. Part 3 shows the major result and discussion, including Scenario A and Scenario B systems analysis. Part 4 gives the active strategy, and the last part is the conclusions.

\section{Methodology}

\section{The basic situation}

\section{The original data}

The basic data source of this article is from a sewage sludge treatment factory and there are 500 employees, which belongs to Shanghai city in China. An yearly wind speed of $3.25 \mathrm{~m} / \mathrm{s}$ can be found from related data in Shanghai (Shanghai Meteorological Bureau 2019). As the largest city in China, its has 474.6 billion US dollars of GDP in 2018 and 6340.5 square kilometers of land area. The sludge comes from municipal sewage in Shanghai, which must satisfy the mandatory national standards (GB 18918-2002).

\section{Sewage sludge treatment and reuse process}

Based on the statistics in the factory, vital data are given as follows: 12,100 tons/year of sludge volume, truck transport distance of $10 \mathrm{~km}$, and $18.76 \$ /$ ton of mud treatment service fee. All calculations are based on US dollars, and the exchange rate is 6.87RMB:1US\$.

Figure 1 illustrates the sludge reuse system craft process. In Fig. 2, as the subsystem in the Scenario B system, the brick production process is made up of bottom ash storage procedure, pretreatment process, screening process, stirring process, and molding process. Bottom ash is the residue product after the sludge treatment process. Besides, some other materials are needed to support the brick production process, including cement, tap water, steel slag, gravel, and limestone.

\section{Emergy approach}

\section{Emergy analysis (EmA)}

The emergy concept is defined as the effective energy and the unit is solar emergy (sej). It was put forward by Odum (1996) firstly. Emergy is an all-around view and contains the direct input, indirect part, energy part, and labor and service section. The emergy approach can integrate some sections into the unified platform to evaluate the environmental level (Luís et al. 2016; Brown et al. 2012). Specifically speaking, the environmental sustainability of sludge reuse can be assessed by transforming all kinds of physical units, involving energy (J), mess (kg), and financial (\$) (Wei et al. 2016). Through multiplied by unit emergy values (UEVs), various types of emergy can be calculated (Zhou et al. 2009), containing emergy/energy (sej/j), specific emergy (sej/g), and emergy/money (sej/\$), respectively (Yan et al. 2018).

Emergy baseline is another pivotal issue that will impact on accuracy in sludge reuse system sustainability, and it illustrates emergy of biosphere, including solar, tidal, and geothermal energy. Until now, there are currently five baselines, which are 9.44E+24sej/year (Odum 1996), 9.26E+24sej/year (Campbell, 1998), 15.83E+24sej/year (Odum 2000), 15.2E+24sej/year (Brown and Ulgiati 2010), $12 \mathrm{E}+24 \mathrm{sej} / \mathrm{year}$ (Brown and Ulgiati 2016a), respectively. In this article, the latest emergy baseline of $12 \mathrm{E}+24 \mathrm{sej} / \mathrm{year}$ was used to calculate emergy in sludge reuse system.

\section{Emergy diagrams of the sewage sludge treatment systems (Scenario A and Scenario B)}

There are two Scenarios for the sewage sludge treatment system, as shown in Figs. 3 and 4. The most significant difference between them is the sludge reuse system consideration. Compared to Scenario A, sludge treatment and reuse system are integrated into the process (Green part in Scenario B). In Fig. 4, non-renewable resources are needed for the brick production system, involving cement, tap water, steel slag, gravel, and limestone. The renewable energy is composed of sunlight energy, rain energy, wind energy, and heat energy.

\section{Ecological sustainable indexes}

Several indexes will be utilized in two sludge reuse system assessments (Scenario A and Scenario B) in Table 2.

1. Renewability rate $\left(R_{\mathrm{r}}\right)$ : the rate that entire emergy divided by renewable part. The bigger the number, the better the sustainability.

2. Non-renewability rate $\left(N_{\mathrm{r}}\right)$ shows the ratio of nonrenewable resources to total emergy. Lower $N_{\mathrm{r}}$ illustrates better sustainable level. 


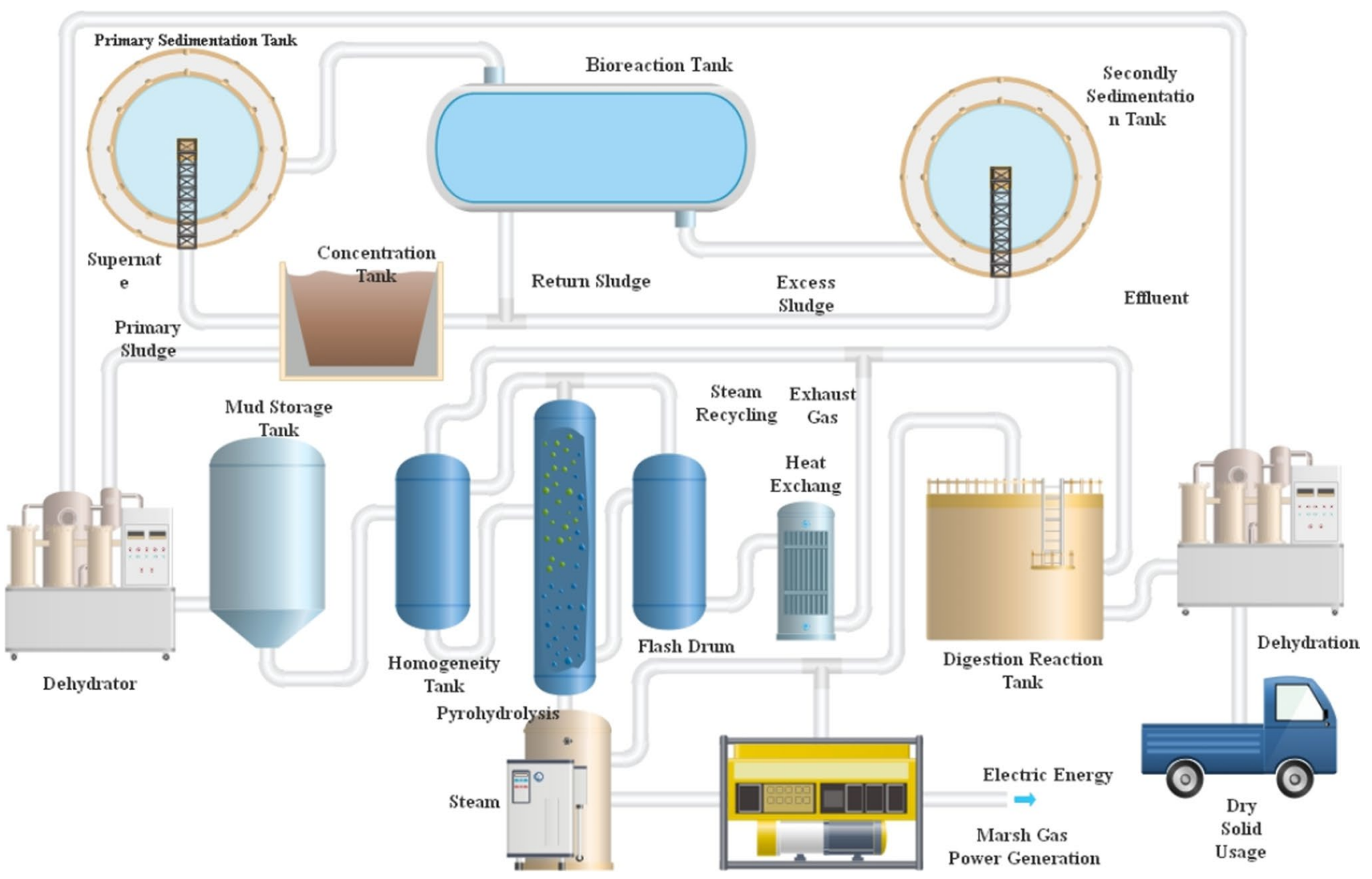

Fig. 1 Sewage sludge reuse system craft

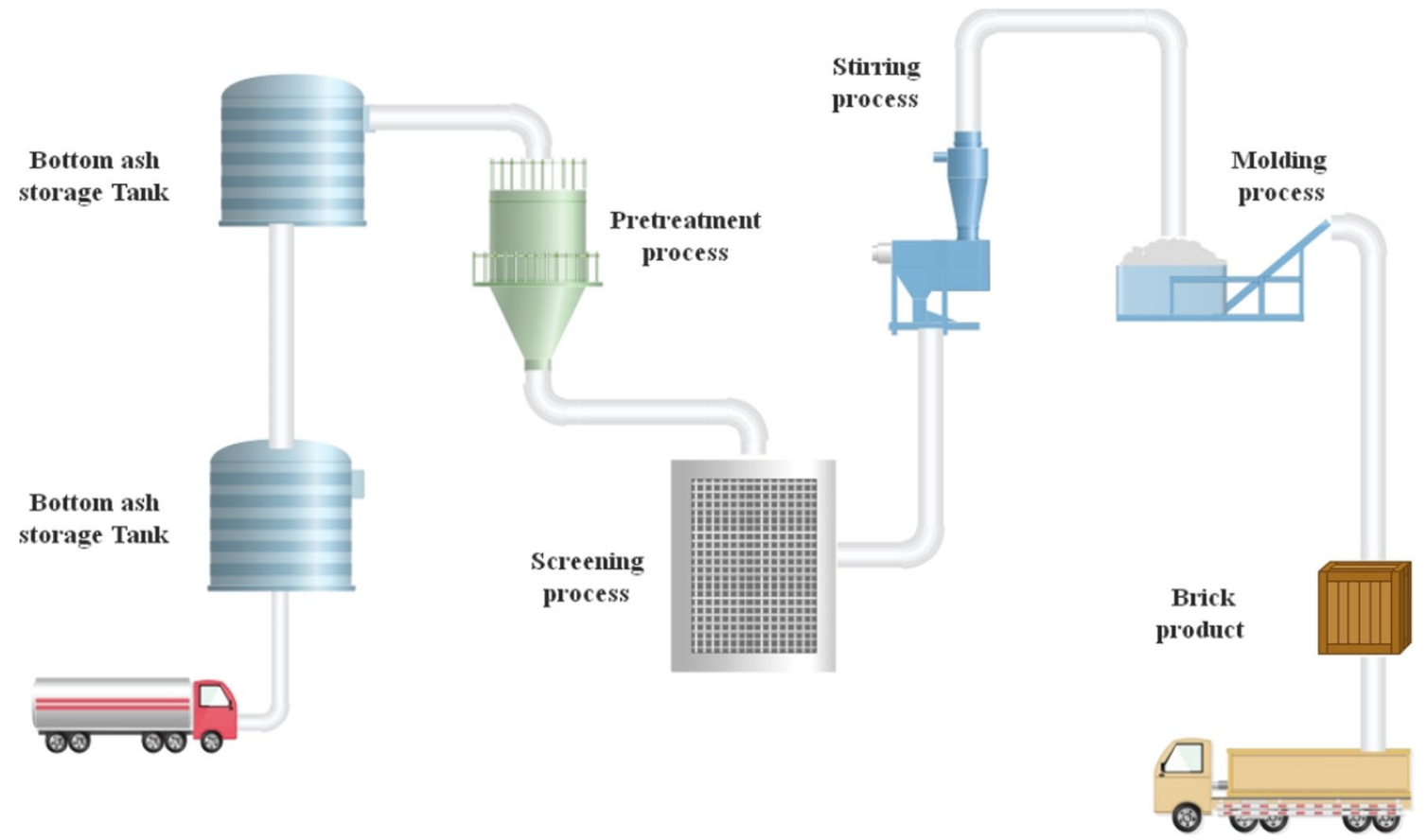

Fig. 2 Small brick production subsystem in Scenario B 
Fig. 3 Scenario A: the original emergy flow of sewage sludge treatment system

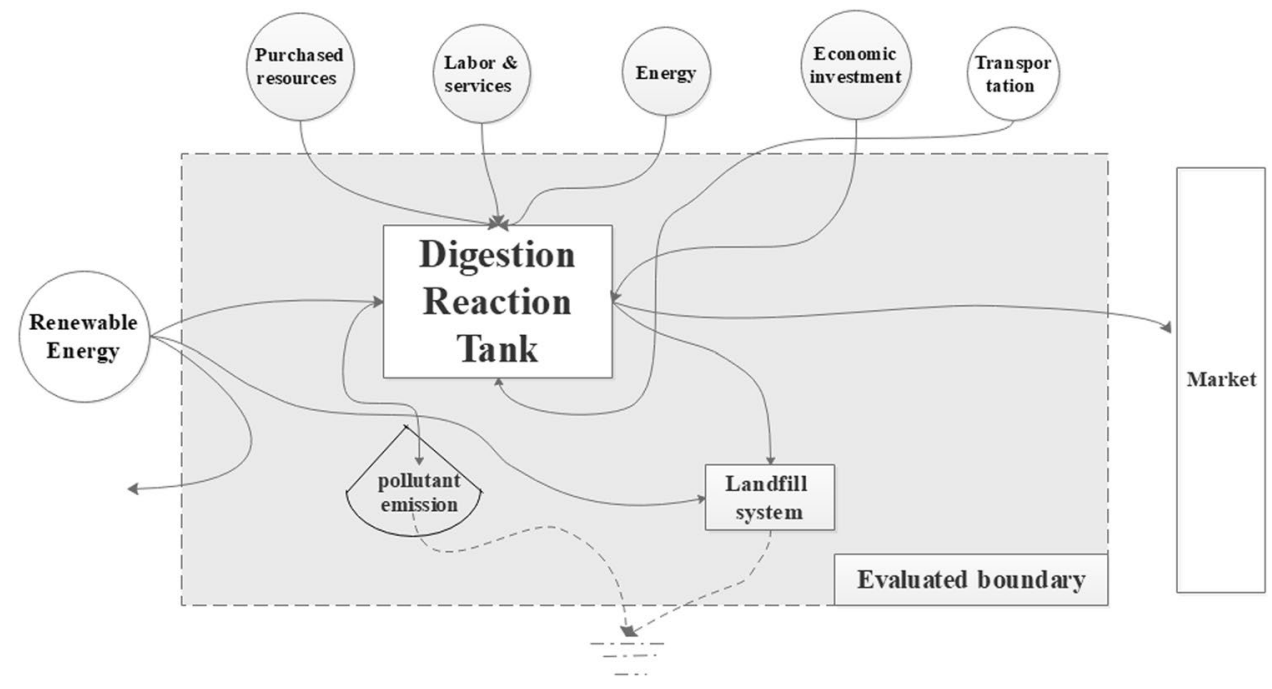

Fig. 4 Scenario B: the improved emergy flow of sewage sludge treatment system

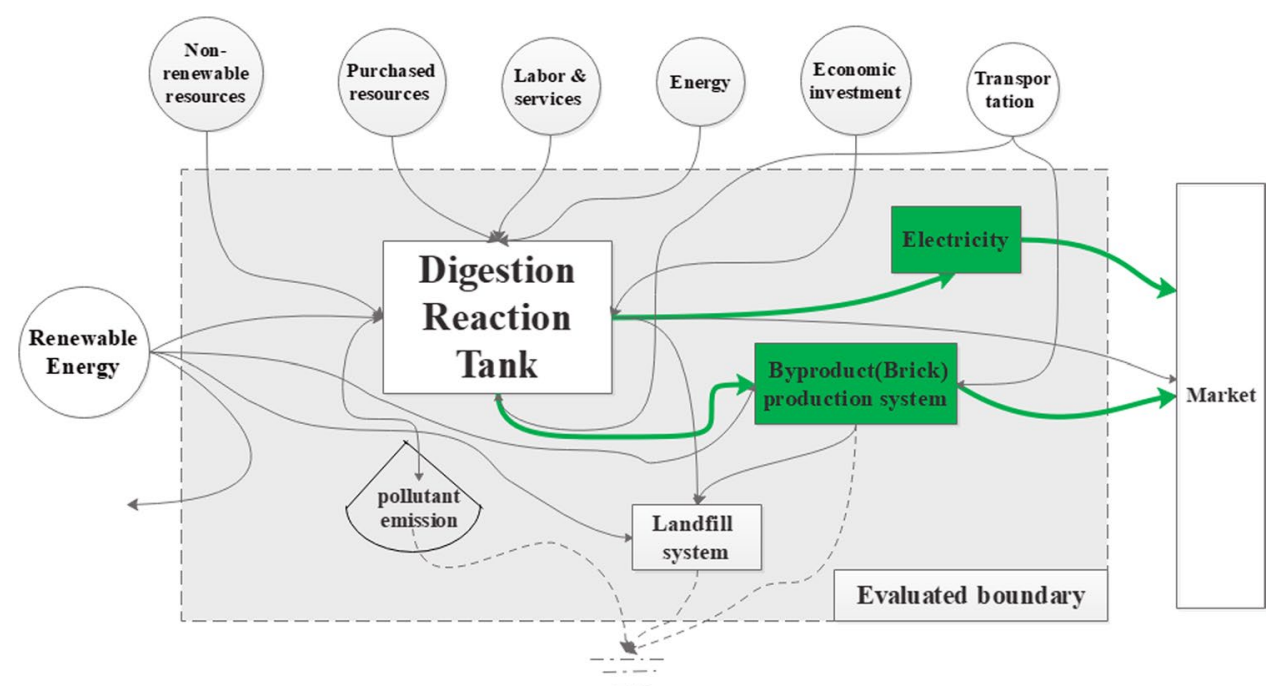

3. Non-renewability rate of purchased resource $\left(N_{\mathrm{p}}\right)$ is the rate between purchased input and emergy sum. The smaller the number, the better the sustainability.

4. Emergy personal density $\left(E_{\mathrm{d}}\right)$ is the emergy of one person. It means a high amount reveals good environmental state.

5. Emergy intensity $\left(E_{\mathrm{i}}\right)$ means the emergy amount of unit area that shows emergy efficiency.

6. Pollutant environmental impact rate (PEIR) is pollutants emergy ratio. Larger value demonstrates poor environmental sustainability.

7. Emergy yield ratio (EYR): EYR represents the ability of generating emergy. The lower the EYR is, the worse the result of sludge reuse system is (Ulgiati and Brown 2002).

8. Environmental loading ratio (ELR): It can be utilized to display the environmental load in the system. Gen- erally speaking, there are three standards for the ELR, which are acceptable standard (Less than 2), basic qualifications $(3<E L R<10)$, and unqualified result (more than 10) (Cao and Feng 2007).

9. Emergy sustainability index (ESI): It is a proportion between EYR and ELR, which represents the sustainability in the system. In general, three standards have been adopted (Cao and Feng 2007), including ESI $<1$ (poor), $1<$ ESI < 5(qualified), and ESI $>5$ (good).

10. Unit emergy values (UEVs) demonstrate emergy amount based on a unit of substance, energy, labor service, and money, which shows the effect in the process (Brown et al. 2012). 
Table 2 Total indexes in two sludge reuse systems

\begin{tabular}{ll}
\hline Types & Meaning \\
\hline Renewable energy emergy $(R)$ & Fundamental view \\
Non-renewable resource emergy $(F)$ & Fundamental view \\
Purchased emergy $(P)$ & Fundamental view \\
Wastewater treatment chemicals emergy $(C)$ & Fundamental view \\
Labor and service emergy $(L)$ & Fundamental view \\
Energy emergy $(E)$ & Fundamental view \\
Transportation emergy $(S)$ & Fundamental view \\
Pollutant emergy $\left(P_{\mathrm{e}}\right)$ & Fundamental view \\
Entire emergy $(T)$ & Entire emergy \\
Renewability rate $\left(R_{\mathrm{r}}\right)$ & Renewable ratio \\
Non-renewability rate of local resource $\left(N_{\mathrm{r}}\right)$ & Local resource ratio \\
Non-renewability rate of purchased resource $\left(N_{\mathrm{p}}\right)$ & Outside economic impact \\
Emergy personal density $\left(E_{\mathrm{d}}\right)$ & Emergy per person \\
Emergy intensity $\left(E_{\mathrm{i}}\right)$ & Emergy per area \\
Pollutant environmental impact rate $($ PEIR) & Pollutant level \\
Environmental loading ratio $($ ELR) & Environmental stress \\
Emergy yield rate $(E Y R)$ & Financial effect \\
Emergy Sustainability Index $(E S I)$ & Sustainable state \\
\hline
\end{tabular}

\section{Sensitivity analysis}

As a test of effectiveness, sensitivity analysis must be checked after the emergy evaluation in the system. So as to enhance the efficiency, it can be computed on account of emergy elerment error variation and the formula can be utilized as (1):

$E_{\mathrm{m}}(i)=\left[\left(E+\varepsilon_{e}\right) \times i\right] \times\left[\left(T+\varepsilon_{t}\right) \times i\right]$

where $E_{\mathrm{m}}$ shows emergy value; $E$ displays energy (J), mess $(\mathrm{kg})$, and economical (\$), respectively; $T$ is emergy conversion rate, $\varepsilon_{e}$ represents the error, and $\varepsilon_{t}$ signifies the failure (Hwang and William 2015).

\section{Waste gas emergy calculations of sludge reuse systems}

\section{Basic emission situation}

In Figs. 3 and 4, exhaust gas has been shown in sludge treatment system a and sludge treatment system B. On the basis of the national standard (GB 13223-2011), dust, sulfur dioxide, nitrogen oxides, carbon dioxide, and nitrous oxide will be produced in sludge treatment A system and sludge treatment B system. Respiratory disease and bad ecological balance will be generated because of exhaust gases so as to harm ecosystem sustainability of sludge reuse (Zhang et al. 2009). To achieve the overall assessment, there are two aspects that need to compute, involving ecological service emergy and economic loss emergy. After waste gas treatment process, the basic data become $35 \mu \mathrm{g} / \mathrm{m}^{3}$ (dust), $50 \mu \mathrm{g} / \mathrm{m}^{3}\left(\mathrm{SO}_{2}\right), 80 \mu \mathrm{g} / \mathrm{m}^{3}$ (NOx), $200 \mu \mathrm{g} / \mathrm{m}^{3}\left(\mathrm{CO}_{2}\right), 80 \mu \mathrm{g} /$ $\mathrm{m}^{3}\left(\mathrm{~N}_{2} \mathrm{O}\right)$ based on ambient air quality standard (National mandatory standard in China) (GB3095-2012).

\section{Economic loss accounting}

As part of the emergy calculation, the economic losses of exhaust gas must be considered and calculated in the two systems. In light of the DALY in Table 3, human health impact can be calculated using formula 2. Relevant literature can be referred to Bakshi (2002) and Liu et al. (2013).

$L=\sum W_{\mathrm{i}} \times D A L Y_{i} \times \alpha$

$L$ represents emergy loss because of the human health effect (sej/a); $I$ shows the gas item. $W_{\mathrm{i}}$ is the waste gas amount. DALY is the impact item $(\mathrm{a} / \mathrm{kg}) . \alpha$ is emergy to humans per

Table 3 DALY data of exhaust gas emission emissions in this article (Yan et al. 2018)

\begin{tabular}{llll}
\hline Name of gas & Amount/y & $\begin{array}{l}\text { Damage impact on } \\
\text { human health }\end{array}$ & $\begin{array}{l}\text { DALY }(\mathrm{a} / \mathrm{Kg} \\
\text { of discharge })\end{array}$ \\
\hline Dust & $1.44 \mathrm{E} 04 \mathrm{~kg}$ & Respiratory & $5.46 \mathrm{E}-05$ \\
$\mathrm{SO}_{2}$ & $2.97 \mathrm{E} 03 \mathrm{~kg}$ & Respiratory & $8.87 \mathrm{E}-05$ \\
$\mathrm{NO}_{\mathrm{X}}$ & $1.75 \mathrm{E} 03 \mathrm{~kg}$ & Respiratory & $3.75 \mathrm{E}-04$ \\
$\mathrm{CO}_{2}$ & $7.83 \mathrm{E} 05 \mathrm{~kg}$ & Climate change & $2.10 \mathrm{E}-07$ \\
$\mathrm{~N}_{2} \mathrm{O}$ & $6.92 \mathrm{E} 02 \mathrm{~kg}$ & Respiratory & $6.90 \mathrm{E}-05$ \\
\hline
\end{tabular}


year and is $1.68 \mathrm{E} 16 \mathrm{sej} /(\mathrm{a} \cdot$ person) on the basis of the baseline 12.0E24sej/a (Yan et al. 2018) (Table 4).

\section{Ecological services calculation}

Another part of exhaust gas emergy calculation is ecological services, which have also a passive environmental impact. Therefore, emergy assessment of five waste gases should be computed, including two steps.

Firstly, the exhaust gas amount can be calculated by using formula (3).

$M_{i}=c \times\left(\frac{U_{i} \times 10^{6}}{s_{i}}\right)$

Therein, $M_{i}$ is the dilution air mass $(\mathrm{Kg} / \mathrm{a})$. I shows gas item. c represents air density $\left(1.23 \mathrm{~kg} / \mathrm{m}^{3}\right) . U_{i}$ means the annual air pollutants mass $(\mathrm{Kg} / \mathrm{a}) . \mathrm{s}_{i}$ represents the acceptable concentration $\left(\mathrm{mg} / \mathrm{m}^{3}\right)$. The acceptable concentrations include dust $\left(0.08 \mathrm{mg} / \mathrm{m}^{3}\right) \mathrm{SO}_{2}\left(0.02 \mathrm{mg} / \mathrm{m}^{3}\right), \mathrm{NO}_{\mathrm{x}}(0.05 \mathrm{mg} /$ $\left.\mathrm{m}^{3}\right), 0.2 \mu \mathrm{g} / \mathrm{m}^{3}\left(\mathrm{CO}_{2}\right)$, and $0.08 \mu \mathrm{g} / \mathrm{m}^{3}\left(\mathrm{~N}_{2} \mathrm{O}\right)$, respectively (GB3095-2012). Secondly, the emergy of ecological service needs to be calculate by using formula (4).

$R_{\text {air }, i}=0.5 \times M_{i} \times v^{2} \times T_{\mathrm{w}}$

where $R_{\text {air }, i}$ represents environmental service emergy, sej/a. $v$ is the average wind speed $(3.25 \mathrm{~m} / \mathrm{s}) . T_{\mathrm{w}}$ is wind emergy conversion rate $(1.86 \mathrm{E} 03 \mathrm{sej} / \mathrm{J})$ based on baseline of $12.0 \mathrm{E} 24 \mathrm{sej} / \mathrm{a}[39]$.

\section{Results and discussion}

\section{Emergy calculated table of the sewage treatment sludge plant in China}

\section{Emergy analysis (EmA)}

There are two Scenarios (A and B) that are calculated in Table 5 and Table 6. In Scenario A, the sludge reuse process has been executed, but the sludge reuse measures have not been performed (shown in Table 5).

There are seven parts in Scenario A, containing renewable section, input resource, economic investment, labor and service, energy, transportation, and all the outputs (Mainly exhaust gas). In view of the emergy proportions, input resources, economic investment, and energy are the critical elements for the whole emergy in Scenario A system (at least $96.4 \%$ of the entire emergy). Therein, input resources part is the key contributor, accounting for $59.6 \%$ of emergy sum, followed by energy (22.3\%), economic investment (14.5\%), labor and services $(2.35 \%)$, renewable energy $(0.72 \%)$, transportation $(0.47 \%)$, all the outputs (Mainly exhaust gas) $(0.01 \%)$. In particular, as the cruxes, untreated sludge is the main influencing factors (about 53\%); meanwhile, electricity (Plant usage) and operating costs are the pivotal element for the energy part and economic investment part, which are $22.1 \%$ and $9.73 \%$. Renewable energy $(0.72 \%)$, transportation (0.47\%), all the outputs (Mainly exhaust gas) $(0.01 \%)$ have a small effect on the entire evaluated system in Scenario A.
Table 4 Unit emergy values (UEVs) correction based on $12.00 \mathrm{E} 24 \mathrm{sej} /$ year (Mark et al. 2016)

\begin{tabular}{lllll}
\hline Item & Raw UEVs & $\begin{array}{l}\text { Emergy base- } \\
\text { line (sej/a) }\end{array}$ & References & Corrected UEVs \\
\hline Sunlight & 1 & $12.00 \mathrm{E} 24$ & Jae and William (2017) & $1 \mathrm{sej} / \mathrm{j}$ \\
Rain (chemical) & $2.35 \mathrm{E} 04$ & $12.00 \mathrm{E} 24$ & Jae and William (2017) & $2.35 \mathrm{E} 04 \mathrm{sej} / \mathrm{j}$ \\
Rain (geopotential) & $1.31 \mathrm{E} 04$ & $12.00 \mathrm{E} 24$ & Jae and William (2017) & $1.31 \mathrm{E} 04 \mathrm{sej} / \mathrm{j}$ \\
Wind (kinetic energy) & $1.90 \mathrm{E} 03$ & $12.00 \mathrm{E} 24$ & Jae and William (2017) & $1.90 \mathrm{E} 03 \mathrm{sej} / \mathrm{j}$ \\
Geothermal heat & $4.37 \mathrm{E} 04$ & $12.00 \mathrm{E} 24$ & Wei et al. (2016) & $4.37 \mathrm{E} 04 \mathrm{sej} / \mathrm{j}$ \\
Gravel & $1.42 \mathrm{E} 12$ & $12.00 \mathrm{E} 24$ & Wei et al. $(2016)$ & $1.42 \mathrm{E} 12 \mathrm{sej} / \mathrm{kg}$ \\
Limestone & $1.27 \mathrm{E} 12$ & $12.00 \mathrm{E} 24$ & Wei et al. $(2016)$ & $1.27 \mathrm{E} 12 \mathrm{sej} / \mathrm{kg}$ \\
Cement & $1.93 \mathrm{E} 12$ & $12.00 \mathrm{E} 24$ & Wei et al. (2016) & $1.93 \mathrm{E} 12 \mathrm{sej} / \mathrm{kg}$ \\
Steel slag & $2.75 \mathrm{E} 12$ & $9.44 \mathrm{E} 24$ & Hengyu et al. (2016) & $3.49 \mathrm{E} 12 \mathrm{sej} / \mathrm{kg}$ \\
Tap water & $9.03 \mathrm{E} 11$ & $12.00 \mathrm{E} 24$ & Yan et al. (2018) & $9.03 \mathrm{E} 11 \mathrm{sej} / \mathrm{m}^{3}$ \\
Bottom ash & $7.58 \mathrm{E} 14$ & $12.00 \mathrm{E} 24$ & Yanqing et al. $(2018)$ & $7.58 \mathrm{E} 14 \mathrm{sej} / \mathrm{kg}$ \\
Labor and services & $1.51 \mathrm{E} 10$ & $15.83 \mathrm{E} 24$ & Bo and Sergio $(2013)$ & $1.14 \mathrm{E} 10 \mathrm{sej} / \$$ \\
Investment & $1.89 \mathrm{E} 11$ & $15.2 \mathrm{E} 24$ & Shao and Chen $(2016)$ & $1.49 \mathrm{E} 11 \mathrm{sej} / \$$ \\
Operating cost & $2.05 \mathrm{E} 12$ & $15.2 \mathrm{E} 24$ & Shao and Chen $(2016)$ & $1.62 \mathrm{E} 12 \mathrm{sej} / \$$ \\
Landfill cost & $2.05 \mathrm{E} 12$ & $15.2 \mathrm{E} 24$ & Shao and Chen $(2016)$ & $1.62 \mathrm{E} 12 \mathrm{sej} / \$$ \\
Electricity & $4.50 \mathrm{E} 05$ & $12.00 \mathrm{E} 24$ & Wei et al. (2016) & $4.50 \mathrm{E} 05 \mathrm{sej} / \mathrm{j}$ \\
\hline
\end{tabular}


Table 5 Emergy calculated details of original sludge treatment process (Scenario A)

\begin{tabular}{|c|c|c|c|c|c|c|}
\hline \multicolumn{2}{|l|}{ Name } & Basic data & UEVs sej/unit & Ref. for UEVs & Emergy (sej/y) & $\%$ \\
\hline \multicolumn{5}{|c|}{ 1-Renewable Energy (See Appendix 1 for the specific calculation process) } & 2.39E16 & 0.72 \\
\hline \multicolumn{2}{|l|}{ Sunlight } & $1.32 \mathrm{E} 08 \mathrm{~J} / \mathrm{yr}$ & 1 & Jae and William (2017) & $1.32 \mathrm{E} 08$ & 0.00 \\
\hline \multicolumn{2}{|l|}{ Rain (chemical potential) } & $6.41 \mathrm{E} 11 \mathrm{~J} / \mathrm{yr}$ & $2.35 \mathrm{E} 04$ & Jae and William (2017) & $1.51 \mathrm{E} 16$ & 0.46 \\
\hline \multicolumn{2}{|l|}{ Rain (geo potential) } & $2.80 \mathrm{E} 11 \mathrm{~J} / \mathrm{yr}$ & $2.79 \mathrm{E} 04$ & Jae and William (2017) & 7.81E15 & 0.24 \\
\hline \multicolumn{2}{|l|}{ Wind (kinetic energy) } & $4.43 \mathrm{E} 11 \mathrm{~J} / \mathrm{yr}$ & $1.90 \mathrm{E} 03$ & Jae and William (2017) & $8.42 \mathrm{E} 14$ & 0.03 \\
\hline \multicolumn{2}{|l|}{ Geothermal heat } & $3.51 \mathrm{E} 11 \mathrm{~J} / \mathrm{yr}$ & 3.44E04 & Wei et al. (2016) & $1.27 \mathrm{E} 14$ & 0.00 \\
\hline \multicolumn{2}{|l|}{ 2-Input resources } & & & & 1.97E18 & 59.6 \\
\hline \multicolumn{2}{|l|}{ Untreated sludge } & $1.21 \mathrm{E} 07 \mathrm{~kg}$ & $1.45 \mathrm{E} 11$ & Gengyuan et al. (2015) & $1.75 \mathrm{E} 18$ & 53.0 \\
\hline \multicolumn{2}{|l|}{ Flocculant } & $3.41 \mathrm{E} 02 \mathrm{~kg}$ & $6.38 \mathrm{E} 14$ & Brown and Ulgiati (2010) & $2.18 \mathrm{E} 17$ & 6.61 \\
\hline \multicolumn{2}{|l|}{ 3- Economic investment } & & & & 4.80E17 & 14.5 \\
\hline \multicolumn{2}{|l|}{ Investment } & $3.74 \mathrm{E} 05 \$$ & $1.49 \mathrm{E} 11$ & Shao and Chen (2016) & $5.57 \mathrm{E} 16$ & 1.69 \\
\hline \multicolumn{2}{|l|}{ Operating cost } & $1.98 \mathrm{E} 05 \$$ & $1.62 \mathrm{E} 12$ & Shao and Chen (2016) & $3.21 \mathrm{E} 17$ & 9.73 \\
\hline \multicolumn{2}{|l|}{ Landfill cost } & $6.36 \mathrm{E} 04 \$$ & $1.62 \mathrm{E} 12$ & Shao and Chen (2016) & $1.03 \mathrm{E} 17$ & 3.12 \\
\hline \multicolumn{2}{|l|}{ 4-Labor and services } & & & & 7.74E16 & 2.35 \\
\hline \multicolumn{2}{|l|}{ Labor and services } & $3.02 \mathrm{E} 05 \$$ & $1.14 \mathrm{E} 10$ & Bo and Sergio (2013) & $3.44 \mathrm{E} 15$ & 0.10 \\
\hline \multicolumn{2}{|l|}{ Governmental subsidies } & $4.57 \mathrm{E} 04 \$$ & $1.62 \mathrm{E} 12$ & Shao and Chen (2016) & $7.40 \mathrm{E} 16$ & 2.24 \\
\hline \multicolumn{2}{|l|}{ 5-Energy } & & & & 7.35E17 & 22.3 \\
\hline \multicolumn{2}{|l|}{ Electricity (Plant usage) } & $1.62 \mathrm{E} 12 \mathrm{~J}$ & $4.50 \mathrm{E} 05$ & Wei et al. (2016) & $7.29 \mathrm{E} 17$ & 22.1 \\
\hline \multicolumn{2}{|l|}{ Coal (fuel in turbine) } & $5.43 \mathrm{E} 10 \mathrm{~J}$ & $1.11 \mathrm{E} 05$ & Brown and Ulgiati (2010) & $6.03 \mathrm{E} 15$ & 0.18 \\
\hline \multicolumn{2}{|l|}{ 6-Transportation } & & & & 1.55E16 & 0.47 \\
\hline \multicolumn{2}{|l|}{ Transportation } & 2.04E04 t·km & $7.61 \mathrm{E} 11$ & Wei et al. (2016) & $1.55 \mathrm{E} 16$ & 0.47 \\
\hline \multicolumn{4}{|c|}{ 7-All the outputs (Mainly exhaust gas) } & & 4.70E14 & 0.01 \\
\hline \multirow[t]{5}{*}{ Exhaust gas emissions } & Dust & $35 \mu \mathrm{g} / \mathrm{m}^{3}$ & GB3095-2012 & & $2.49 \mathrm{E} 13$ & 0.00 \\
\hline & $\mathrm{SO}_{2}$ & $50 \mu \mathrm{g} / \mathrm{m}^{3}$ & GB3095-2012 & & $4.46 \mathrm{E} 13$ & 0.00 \\
\hline & $\mathrm{NO}_{\mathrm{X}}$ & $80 \mu \mathrm{g} / \mathrm{m}^{3}$ & GB3095-2012 & & $1.11 \mathrm{E} 14$ & 0.00 \\
\hline & $\mathrm{CO}_{2}$ & $200 \mu \mathrm{g} / \mathrm{m}^{3}$ & GB3095-2012 & & $1.78 \mathrm{E} 14$ & 0.01 \\
\hline & $\mathrm{N}_{2} \mathrm{O}$ & $80 \mu \mathrm{g} / \mathrm{m}^{3}$ & GB3095-2012 & & $1.11 \mathrm{E} 14$ & 0.00 \\
\hline Total & \multicolumn{4}{|l|}{$\sim$} & 3.30E18 & 100 \\
\hline \multicolumn{7}{|c|}{ atment and reuse system (Sce } \\
\hline
\end{tabular}

All calculated emergy baseline is $12.00 \mathrm{E}+24 \mathrm{sej} / \mathrm{yr}$ and the related calculations can be found in Appendix 1

Compared to Scenario A, Scenario B is a comprehensive system, which integrates the sewage sludge treatment system and brick production system for sludge recycling.

Eight subsections contribute to the emergy proportions, containing renewable energy $(0.31 \%)$, non-renewable resources $(27.5 \%)$, input resource $(37.2 \%)$, economic investment $(6.30 \%)$, labor and service $(1.02 \%)$, energy $(9.65 \%)$, transportation $(0.20 \%)$, and all the outputs (18\% of exhaust gas emissions, electricity and products' economic benefit). As the main contributors, non-renewable resources, input resource, economic investment, energy, and outputs play the decisive impact on the sustainability evaluation, which account for $98.65 \%$ of the whole emergy in the Scenario $\mathrm{B}$ system. The input resource acts as a pivotal role, composing of untreated sludge $(22.9 \%)$, flocculant $(2.86 \%)$, and bottom ash (11.3\%). Among them, untreated sludge is the crucial part and has $61.6 \%$ ratio for the entire input resource emergy. Non-renewable resource plays a second important role, containing cement $(13.8 \%)$, tap water $(0.49 \%)$, steel slag $(10.2 \%)$, gravel $(2.99 \%)$, limestone $(0.02 \%)$. Hence, in the non-resource input, cement, steel slag, and gravel occupy the dominant positions. All the outputs (exhaust gas emissions, electricity and products' economic benefit) hold a third influence (18\%) for the complete result because of the joint brick production system in Scenario B. In the outputs, electricity (9.57\%) and products' economic benefit $(8.44 \%)$ is the main force compared to the exhaust gas emissions (near zero), which consists of dust, $\mathrm{SO}_{2}, \mathrm{NO}_{\mathrm{X}}, \mathrm{CO}_{2}$, and $\mathrm{N}_{2} \mathrm{O}$. In addition, the energy $(9.65 \%)$ and economic investment $(6.30 \%)$ have the function which cannot be ignored in the whole assessment of Scenario B.

Finally, labor and service $(1.02 \%)$ are not significant factors in Scenario B, while renewable energy $(0.31 \%)$ and transportation $(0.20 \%)$ have almost no effect in Scenario B.

Compared with Scenario A and Scenario B, the most significant difference is the brick production system 
Table 6 Emergy calculated details of improved sludge treatment process (Scenario B)

\begin{tabular}{|c|c|c|c|c|c|c|}
\hline Name & Formula ratio & Basic data & UEVs sej/unit & Ref. for UEVs & Emergy (sej/y) & $\%$ \\
\hline \multicolumn{5}{|c|}{ 1-Renewable Energy (See Appendix 2 for the specific calculation process) } & 2.39E16 & 0.31 \\
\hline Sunlight & & $1.32 \mathrm{E} 08 \mathrm{~J} / \mathrm{yr}$ & 1 & Jae and William (2017) & $1.32 \mathrm{E} 08$ & 0.00 \\
\hline Rain (chemical potential) & & $6.41 \mathrm{E} 11 \mathrm{~J} / \mathrm{yr}$ & $2.35 \mathrm{E} 04$ & Jae and William (2017) & $1.51 \mathrm{E} 16$ & 0.20 \\
\hline Rain (geo potential) & & $2.80 \mathrm{E} 11 \mathrm{~J} / \mathrm{yr}$ & 2.79E04 & Jae and William (2017) & $7.81 \mathrm{E} 15$ & 0.10 \\
\hline Wind (kinetic energy) & & $4.43 \mathrm{E} 11 \mathrm{~J} / \mathrm{yr}$ & $1.90 \mathrm{E} 03$ & Jae and William (2017) & $8.42 \mathrm{E} 14$ & 0.01 \\
\hline Geothermal heat & & $3.51 \mathrm{E} 11 \mathrm{~J} / \mathrm{yr}$ & $3.44 \mathrm{E} 04$ & Wei et al. (2016) & $1.27 \mathrm{E} 14$ & 0.00 \\
\hline \multicolumn{5}{|c|}{ 2-Non-renewable resources (mainly for the brick production subsystem usages) } & 2.09E18 & 27.5 \\
\hline Cement & & $5.44 \mathrm{E} 05 \mathrm{~kg}$ & $1.93 \mathrm{E} 12$ & Wei et al. (2016) & $1.05 \mathrm{E} 18$ & 13.8 \\
\hline Tap water & & $1.45 \mathrm{E} 04 \mathrm{~m}^{3}$ & 9.03E11 & Yan et al. (2018) & $3.71 \mathrm{E} 16$ & 0.49 \\
\hline Steel slag & & $2.83 \mathrm{E} 05 \mathrm{~kg}$ & $2.75 \mathrm{E} 12$ & Hengyu et al. (2016) & $7.78 \mathrm{E} 17$ & 10.2 \\
\hline Gravel & & $2.03 \mathrm{E} 05 \mathrm{~kg}$ & $1.42 \mathrm{E} 12$ & Wei et al. (2016) & $2.28 \mathrm{E} 17$ & 2.99 \\
\hline Limestone & & $1.31 \mathrm{E} 03 \mathrm{~kg}$ & $1.27 \mathrm{E} 12$ & Wei et al. (2016) & $1.66 \mathrm{E} 15$ & 0.02 \\
\hline 3-Input resources & & & & & 2.83E18 & 37.2 \\
\hline Untreated sludge & & $1.21 \mathrm{E} 07 \mathrm{~kg}$ & $1.45 \mathrm{E} 11$ & Gengyuan et al. (2015) & $1.75 \mathrm{E} 18$ & 22.9 \\
\hline Flocculant & & $3.41 \mathrm{E} 02 \mathrm{~kg}$ & $6.38 \mathrm{E} 14$ & Brown and Ulgiati (2010) & $2.18 \mathrm{E} 17$ & 2.86 \\
\hline Bottom ash (Brick plant) & & $1.14 \mathrm{E} 03 \mathrm{~kg}$ & $7.58 \mathrm{E} 14$ & Yanqing et al. (2018) & $8.64 \mathrm{E} 17$ & 11.3 \\
\hline 4-Economic investment & & & & & $4.80 \mathrm{E} 17$ & 6.30 \\
\hline Investment & & $3.74 \mathrm{E} 05 \$$ & 1.49E11 & Shao and Chen (2016) & $5.57 \mathrm{E} 16$ & 0.73 \\
\hline Operating cost & & $1.98 \mathrm{E} 05 \$$ & $1.62 \mathrm{E} 12$ & Shao and Chen (2016) & $3.21 \mathrm{E} 17$ & 4.21 \\
\hline Landfill cost & & $6.36 \mathrm{E} 04 \$$ & $1.62 \mathrm{E} 12$ & Shao and Chen (2016) & $1.03 \mathrm{E} 17$ & 1.35 \\
\hline 5-Labor and services & & & & & 7.74E16 & 1.02 \\
\hline Labor and services & & $3.02 \mathrm{E} 05 \$$ & $1.14 \mathrm{E} 10$ & Bo and Sergio (2013) & $3.44 \mathrm{E} 15$ & 0.05 \\
\hline Governmental subsidies & & $4.57 \mathrm{E} 04 \$$ & $1.62 \mathrm{E} 12$ & Shao and Chen (2016) & $7.40 \mathrm{E} 16$ & 0.97 \\
\hline 6-Energy & & & & & 7.35E17 & 9.65 \\
\hline Electricity (Plant usage) & & $1.62 \mathrm{E} 12 \mathrm{~J}$ & $4.50 \mathrm{E} 05$ & Wei et al. (2016) & $7.29 \mathrm{E} 17$ & 9.57 \\
\hline Coal (fuel in turbine) & & $5.43 \mathrm{E} 10 \mathrm{~J}$ & $1.11 \mathrm{E} 05$ & Brown and Ulgiati (2010) & $6.03 \mathrm{E} 15$ & 0.08 \\
\hline 7-Transportation & & & & & $1.55 \mathrm{E} 16$ & 0.20 \\
\hline Transportation (truck) & & 2.04E04 t·km & $7.61 \mathrm{E} 11$ & Wei et al. (2016) & $1.55 \mathrm{E} 16$ & 0.20 \\
\hline 8-All the outputs & & & & & 1.37E18 & 18.0 \\
\hline \multirow[t]{5}{*}{ Exhaust gas emissions } & Dust & $35 \mu \mathrm{g} / \mathrm{m}^{3}$ & Refer Appendix 2 & & $2.49 \mathrm{E} 13$ & 0.00 \\
\hline & $\mathrm{SO}_{2}$ & $50 \mu \mathrm{g} / \mathrm{m}^{3}$ & Refer Appendix & & $4.46 \mathrm{E} 13$ & 0.00 \\
\hline & $\mathrm{NO}_{\mathrm{X}}$ & $80 \mu \mathrm{g} / \mathrm{m}^{3}$ & Refer Appendix 2 & & $1.11 \mathrm{E} 14$ & 0.00 \\
\hline & $\mathrm{CO}_{2}$ & $200 \mu \mathrm{g} / \mathrm{m}^{3}$ & Refer Appendix 2 & & $1.78 \mathrm{E} 14$ & 0.00 \\
\hline & $\mathrm{N}_{2} \mathrm{O}$ & $80 \mu \mathrm{g} / \mathrm{m}^{3}$ & Refer Appendix 2 & & $1.11 \mathrm{E} 14$ & 0.00 \\
\hline Electricity (Power generation) & & & Refer Appendix 2 & & $7.29 \mathrm{E} 17$ & 9.57 \\
\hline Products' economic benefit (brick plant) & & & Refer Appendix 2 & & $6.43 \mathrm{E} 17$ & 8.44 \\
\hline Total & $\sim$ & & & & $7.62 \mathrm{E} 18$ & 100 \\
\hline UEVs & $\mathrm{UEV} \mathrm{s}=\mathbf{6 . 2 9 E}$ & $+11 \mathrm{sej} / \mathbf{k g}$ for th & e sewage sludge tre & atment and reuse system $(\mathrm{Sc}$ & enario B) & \\
\hline
\end{tabular}

All calculated emergy baseline is $12.00 \mathrm{E}+24 \mathrm{sej} / \mathrm{yr}$ and the related calculations can be found in Appendix 2

consideration to improve the sludge treatment and reuse. After considering the brick system (Scenario B), on the one hand, the sludge treatment capacity has been enhanced and raised sludge utilization; on the other hand, negative influences have also generated due to the non-renewable resources input and several outputs.

\section{Emergy indicators calculation}

Ecological indexes of the sludge reuse systems (Scenario A and Scenario B) are displayed in Table 7.

1. The renewability rates $\left(R_{\mathrm{r}}\right)$ are 0.007242 and 0.003136 . The weak sustainability was displayed for both Scenario A and Scenario B. Compared to Scenario A system, Scenario B has worse sustainability. 
Table 7 Calculated results of ecological indicators

\begin{tabular}{llll}
\hline No & Index & Scenario A & Scenario B \\
\hline 1 & $\mathrm{R}$ & $2.39 \mathrm{E}+16 \mathrm{sej}$ & $2.39 \mathrm{E}+16 \mathrm{sej}$ \\
2 & $\mathrm{~F}$ & $\sim$ & $2.09 \mathrm{E}+18 \mathrm{sej}$ \\
3 & $\mathrm{P}$ & $1.97 \mathrm{E}+18 \mathrm{sej}$ & $2.83 \mathrm{E}+18 \mathrm{sej}$ \\
4 & $\mathrm{C}$ & $4.80 \mathrm{E}+17 \mathrm{sej}$ & $4.80 \mathrm{E}+17 \mathrm{sej}$ \\
5 & $\mathrm{~L}$ & $7.74 \mathrm{E}+16 \mathrm{sej}$ & $7.74 \mathrm{E}+16 \mathrm{sej}$ \\
6 & $\mathrm{E}$ & $7.35 \mathrm{E}+17 \mathrm{sej}$ & $7.35 \mathrm{E}+17 \mathrm{sej}$ \\
7 & $\mathrm{~S}$ & $1.55 \mathrm{E}+16 \mathrm{sej}$ & $1.55 \mathrm{E}+16 \mathrm{sej}$ \\
8 & $P_{e}$ & $4.70 \mathrm{E}+14 \mathrm{sej}$ & $1.37 \mathrm{E}+18 \mathrm{sej}$ \\
9 & $\mathrm{~T}$ & $3.30 \mathrm{E}+18 \mathrm{sej}$ & $7.62 \mathrm{E}+18 \mathrm{sej}$ \\
10 & $R_{r}$ & 0.007242 & 0.003136 \\
11 & $N_{r}$ & $\sim$ & 0.274903 \\
12 & $N_{p}$ & 0.596356 & 0.371654 \\
13 & $E_{d}$ & $6.60 \mathrm{E}+15 \mathrm{sej} / \mathrm{per}$ & $1.52 \mathrm{E}+16 \mathrm{sej} / \mathrm{per}$ \\
14 & $E_{i}$ & $5.2 \mathrm{E}+8 \mathrm{sej} / \mathrm{m}^{2}$ & $1.20 \mathrm{E}+9 \mathrm{sej} / \mathrm{m}^{2}$ \\
15 & PEIR & 0.000142 & 0.000062 \\
16 & ELR & 82.362742 & 263.283243 \\
17 & EYR & 1.012383 & 2.232743 \\
18 & ESI & 0.012292 & 0.00848 \\
\hline
\end{tabular}

2. Non-renewability rate of local resources $\left(N_{\mathrm{r}}\right)$ reveals the ratios (0 and 0.274903). Because the sludge reuse was integrated in Scenario B, resulting in a substantial nonrenewable rate. It shows a mass of non-resource input and can give a negative environmental impact. In Scenario A system, the sludge reuse was ignored to execute, so $\mathrm{Nr}$ is zero.

3. Non-renewability rates of input resources $\left(N_{\mathrm{p}}\right)$ are 0.596356 and 0.371654 . Compared to Scenario A system, Scenario A system has less dependency on the input resource. There is an obvious fact and that is superfluous non-resource input resulting in unsustainable state.
4. Emergy personal density $\left(E_{\mathrm{d}}\right)$ is $6.60 \mathrm{E}+15 \mathrm{sej} / \mathrm{per}$ and $1.52 \mathrm{E}+16 \mathrm{sej} / \mathrm{per}$, demonstrating a higher personal emergy in Scenario A and Scenario B system.

5. Emergy intensities $\left(E_{\mathrm{i}}\right)$ are $5.2 \mathrm{E}+8 \mathrm{sej} / \mathrm{m}^{2}$ and $1.20 \mathrm{E}+9$ $\mathrm{sej} / \mathrm{m}^{2}$, which reveal a good land use effect.

6. Pollutant environmental impact rates (PEIRs) are 0.000142 and 0.000062 . They decide the poor influences on total emergy evaluation. In this regard, Scenario B is better than Scenario A.

7. The environmental loading ratios (ELR) are 82.362742 and 263.283243, which show the huge stress. Due to the mass of non-resources input in Scenario B, ELR of Scenario B is 3.2 times of Scenario A. Based on related standard, it is not qualified and need to find ways to optimize the result.

8. Emergy yield ratios (EYR) are 1.012383 and 2.232743. According to the EYR values, they are unqualified; meanwhile, Scenario B has higher EYR based on several non-resources inputs.

9. The emergy sustainability index (ESI) is 0.012292 and 0.00848 . They express the weak comprehensive effects on the evaluated system. Therein, the lack of non-resources in Scenario B leads to higher ESI than Scenario A. Based on the literature, the ESI values of Scenario A and Scenario B have the unsustainable statuses $(<1)$ in the long term.

In Fig. 5, all indicator comparisons have been displayed. According to overall trend consideration in Scenario A and Scenario B, Scenario B has more severe environmental stress and less environmental sustainability than Scenario A. The reason for this phenomenon is the consideration of sewage sludge reuse system in Scenario B, especially for the non-resource input in the brick production system.
Fig. 5 Indicators comparison between Scenario A and Scenario B

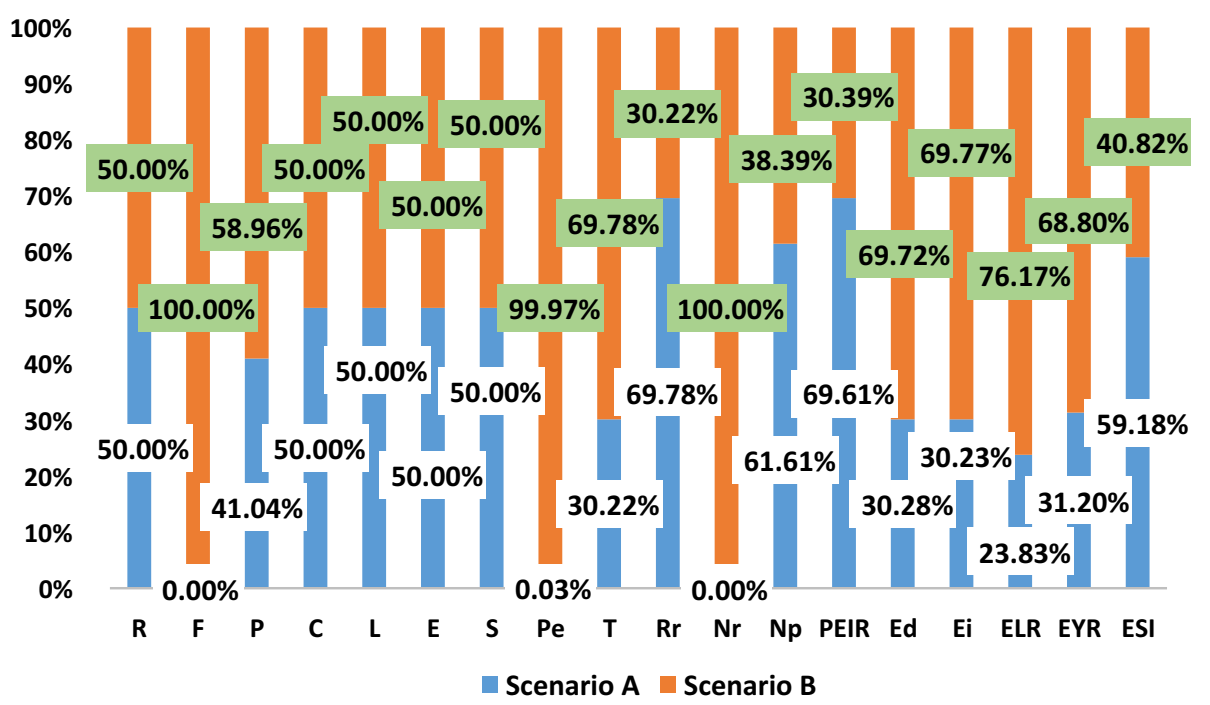


Based on the entire analysis for all indicators, a fact should be demonstrated that the sludge reuse needs more non-resources and financial support, which can lead to several environmental pressures to some extent.

\section{Unit emergy values (UEVs)}

According to the literature review, there is the only article that has been investigated for the UEVs of sludge reuse system in China based on emergy approach[23]. Gengyuan et al. 2015 conducted the sewage sludge reduction and reuse in cement production and four UEVs of sewage sludge treatment and reuse system have been calculated, which are $1.59 \mathrm{E}+12 \mathrm{sej} / \mathrm{kg}, 1.59 \mathrm{E}+12 \mathrm{sej} / \mathrm{kg}, 1.59 \mathrm{E}+12 \mathrm{sej} / \mathrm{kg}$, $1.59 \mathrm{E}+12 \mathrm{sej} / \mathrm{kg}$, respectively[23]. In the published article, the sludge reuse system is the cement production system rather than the brick production system. Due to excess mass and economic investment in the cement production system, the integrated platform system based on sludge treatment system and reuse system (cement production) has a higher environmental load and lower ecological sustainability resulting in larger UEVs.

Compared with the cement production reuse system, the brick production reuse system has distinct advantages, including reduced inputs of non-renewable resources and energy consumption.

Therefore, in this new paper, the UEVs are $2.73 \mathrm{E}+11 \mathrm{sej} /$ $\mathrm{kg}$ and $6.29 \mathrm{E}+11 \mathrm{sej} / \mathrm{kg}$ in Scenario A and Scenario B, respectively. On the basis of the integration platform between the sludge treatment system and reuse system (brick production), it provides the second reference for the new sludge treatment and reuse system in order to enhance the environmental sustainability.

\section{Sensitivity analysis}

In Scenario A system, input resources, economic investment, and energy play the dominant effects in Table 5; meanwhile, non-renewable resources, input resources, economic investment, energy, and outputs are the major contributors in Scenario B system. Sensitivity changes should be considered in Scenario A system and Scenario B system to verify the stability. The assumption is that the major terms vary by $10 \%$, meanwhile, others remain unchanged.

The sensitivity analysis results of indexes are computed in Table 8 and shown in Fig. 6.

Within $10 \%$ changes in these sections, sensitivity change ratios can be concluded in Scenario A and Scenario B, which are $R_{\mathrm{r}}(9.71 \%$ and $8.06 \%), N_{\mathrm{r}}(0$ and $1.53 \%), N_{\mathrm{p}}(0.36 \%$ and $1.68 \%), E_{\mathrm{d}}(9.72 \%$ and $8.07 \%), E_{\mathrm{i}}(9.72 \%$ and $8.07 \%)$ PEIR $(9.39 \%$ and $8.75 \%)$, ELR $(26.97 \%$ and $13.92 \%)$, EYR (19.33\% and $30.01 \%)$, ESI (10.47\% and $18.69 \%)$, respectively.
Table 8 The indicators changes between former and latter in Scenario A and Scenario B

\begin{tabular}{lllllcc}
\hline No & Index & \multicolumn{2}{l}{ Scenario A } & & \multicolumn{2}{l}{ Scenario B } \\
\cline { 6 - 7 } \cline { 6 - 7 } & & Former & Latter & & Former & Latter \\
\hline 1 & $R_{r}$ & 0.007242 & 0.006601 & & 0.003136 & 0.002902 \\
2 & $N_{r}$ & $\sim$ & $\sim$ & 0.274903 & 0.279164 \\
3 & $N_{p}$ & 0.596356 & 0.598491 & & 0.371654 & 0.378006 \\
4 & $E_{d}$ & $6.60 \mathrm{E}+15$ & $6.02 \mathrm{E}+15$ & & $1.52 \mathrm{E}+16$ & $1.41 \mathrm{E}+16$ \\
5 & $E_{i}$ & $5.2 \mathrm{E}+8$ & $4.74 \mathrm{E}+08$ & & $1.20 \mathrm{E}+9$ & $1.11 \mathrm{E}+09$ \\
6 & PEIR & 0.000142 & 0.000129 & & 0.000062 & 0.000057 \\
7 & ELR & 82.3627 & 112.7811 & & 263.2832 & 305.8577 \\
8 & EYR & 1.012383 & 1.254901 & & 2.232743 & 3.190039 \\
9 & ESI & 0.012292 & 0.011127 & & 0.00848 & 0.010429 \\
\hline
\end{tabular}

According to Table 8 and Fig. 6, Scenario B has a broader range of change than Scenario A because of the more resource input. It is found that EYR $(19.33 \%$ and $30.01 \%)$ has the most significant impact, followed by ELR $(26.97 \%$ and $13.92 \%)$ and ESI (10.47\% and $18.69 \%)$. The higher the emergy ratio, the greater the sensitivity impact results in Scenario A system. The same explanations can be for Scenario B system. To sum up, the staple emergy contributor exerts the first implications for sensitivity analysis.

\section{Theoretical value of the parameters}

Input resources part (non-renewable resources) is the key contributor in Scenario A and Scenario B. In order to calculate the theoretical value of the parameters, taking nonrenewable resources as an example, its theoretical value has been counted as follows:

In general, three standards have been adopted (Cao and Feng 2007), including ESI $<1$ (poor), $1<$ ESI $<5$ (qualified), and ESI $>5$ (good). In order to meet the most basic sustainable state, according to sustainability standard, assuming ESI is equal to 1, then ELR is equal to EYR. The new theoretical value of non-renewable resources in Scenario A and Scenario B can be obtained, which are $24.8 \%$ and $7.86 \%$ of the total emergy. Compared to changes in Scenario A and Scenario B, the non-renewable resources proportion changes from 59.6 to $24.8 \%$ in Scenario A, from 27.5 to $7.86 \%$ in Scenario B.

\section{Strategies and suggestions}

In order to ease the negative situation, a number of strategies are put forward for the better sustainability in the sludge reuse systems. 
Fig. 6 Proportion variations between former and latter in Scenario A and Scenario B

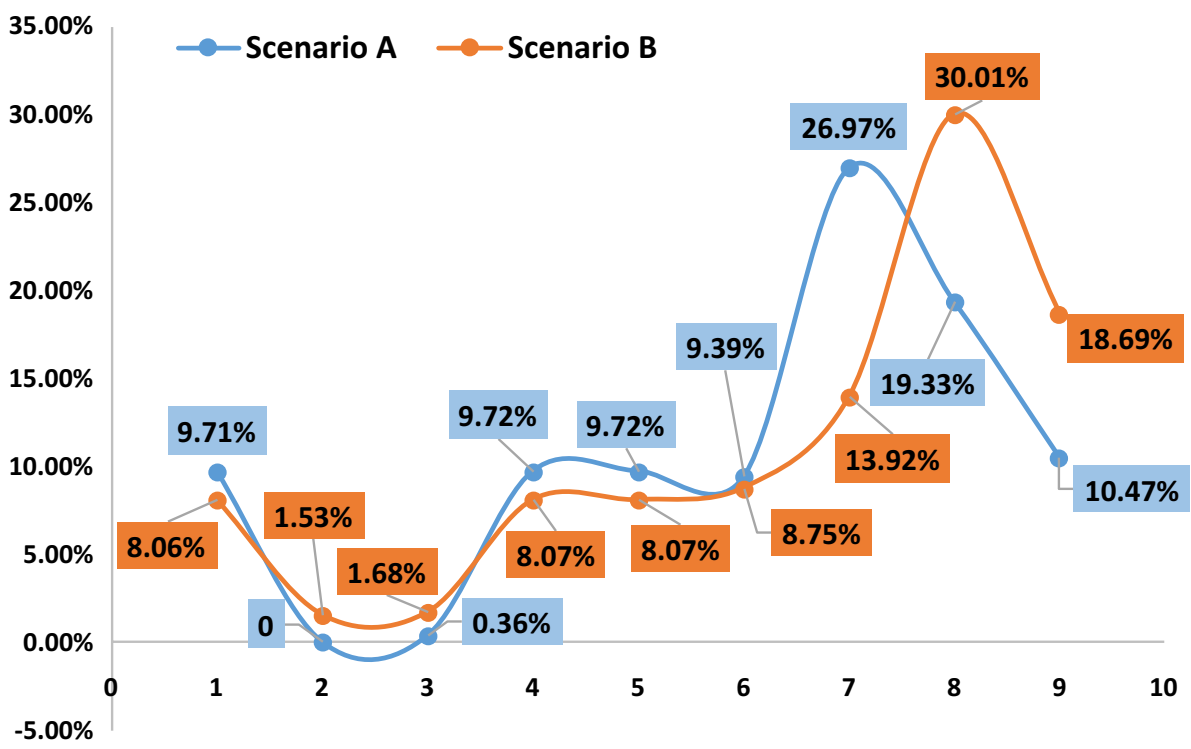

\section{Improving renewable energy input proportion}

According to Tables 5 and 6, the lack of renewable energy results in the passive sustainable impact on the sludge reuse systems. Until now, three types of renewable energy were widely used in China, involving solar power, hydropower, and wind power, which can offer mature technical support. However, some weaknesses block their usages, for instance, high investment, professional barriers, and geographical limit.

Currently, plenty studies have been executed by using renewable energy, which contain solar power (Peronato et al. 2018; Taixiu et al. 2019), hydropower (Ludovic et al. 2014; Shengwen et al. 2019), wind power (Yimin et al. 2019; Sayed et al. 2019); meanwhile, fiscal care can be as beneficial strategies to enhance renewable energy utilization ratio.

\section{Use renewable materials}

Except for the adjustment of the proportion of renewable energy, non-renewable resources should be reduced or replaced by renewable materials. Taking cement as an example, it is a major input for Scenario B system (approximately $13.8 \%$ ). In order to lower the non-renewable resources proportion, several industrial waste and by-products can be utilized, such as industrial waste and constructional residuums. So far, there are a great number of studies that have been conducted through renewable material substitution (Gonçalves et al. 2020; Xingyang et al. 2020). The recycled concrete aggregate has been reused to replace the cement input by Gonçalves et al. (2020), which have a better sustainable effect. On the basis of Xingyang et al. (2020)'s study, wetmilling slurry waste is good alternatives compared to new cement input.

\section{Conclusion}

Based on emergy evaluations in Scenario A and Scenario $\mathrm{B}$, the sustainable assessment of two sewage sludge treatment and reuse systems has been selected and studied in the article. The major contents including:

1. Compared to Scenario A, Scenario B is a comprehensive system, which integrates a sewage sludge treatment system and brick production system for sludge recycling.

2. After considering the brick system (Scenario B), on the one hand, the sludge treatment capacity has been enhanced and raised sludge utilization; on the other hand, negative influences have also generated due to the non-renewable resources input and several outputs.

3. In Scenario A, input resources part plays a dominant role, accounting for $59.6 \%$ of sum of emergy, followed by energy ( $22.3 \%)$, economic investment $(14.5 \%)$, labor and services $(2.35 \%)$, renewable energy $(0.72 \%)$, transportation $(0.47 \%)$, all the outputs (Mainly exhaust gas) $(0.01 \%)$

4. As the main contributors, non-renewable resources, input resource, economic investment, energy, and outputs play the decisive impact on the sustainability evaluation, which account for $98.65 \%$ of the whole emergy in the Scenario B system.

5. Scenario B has more severe environmental stress and less environmental sustainability than Scenario A. The reason for this phenomenon is the consideration of sewage sludge reuse system in Scenario B, especially for the non-resource input in the brick production system.

6. In this new paper, the UEVs are $2.73 \mathrm{E}+11 \mathrm{sej} / \mathrm{kg}$ and $6.29 \mathrm{E}+11 \mathrm{sej} / \mathrm{kg}$ in Scenario A and Scenario B, respectively. 
7. The emergy sustainability index (ESI) is 0.012292 and 0.00848 , which express the weak comprehensive effects in Scenario A and Scenario B. Scenario B has a more massive range of change than Scenario $A$ because of the more resource input.

8. Scenario B has a broader range of change than Scenario A because of the more resource input. It is found that EYR (19.33\% and 30.01\%) has the most significant impact, followed by ELR (26.97\% and $13.92 \%)$ and ESI (10.47\% and $18.69 \%)$.

In spite, the integrated reuse system (Scenario B) can improve the sludge reuse capacity than without an integrated reuse system (Scenario A), but it will cause a certain amount of environmental stress resulting in negative sustainability. Thence, two active suggestions are raised related to renewable energy and recycled materials.

\section{Appendix 1 (Table 5)}

1. Renewable Energy calculation:

(1) Solar energy calculation: Area of Scenario A system $=3.18 E+05 \mathrm{~m}^{2}$; Insolation (Hubei Province, China) $=5.43 \times 109 \mathrm{~J} / \mathrm{m}^{2} / \mathrm{yr} ;$ Albedo $=0.30$ (Lou and Ulgiati 2013). Energy $=($ solation $) \times(1-$ albedo $) \times($ area $)$ $=\left(5.43 \times 109 \mathrm{~J} / \mathrm{m}^{2} / \mathrm{yr}\right) \times(1-0.30) \times\left(3.18 E+05 \mathrm{~m}^{2}\right)$ $=1.32 E+08 \mathrm{~J} / \mathrm{yr}$. UEV $=1.00 \mathrm{sej} / \mathrm{J}$ by definition. Emergy $=1.32 E 08 \mathrm{~J} / \mathrm{yr} \times 1 \mathrm{yr} \times 1 \mathrm{sej} / \mathrm{J}$ $=1.32 E 08 \mathrm{sej}$

(2) Rain (chemical potential energy) calculation: Area of Scenario A system $=3.18 \mathrm{E}+05 \mathrm{~m}^{2}$;

Rainfall (annual average, $n=5$ ) $=0.68 \mathrm{~m} /$ year (Jiangsu Provincial Bureau of Statistics, China, $2012-2016$.);

Water density $=1.00 \mathrm{~kg} / \mathrm{m}^{3} ;$ Evapotranspiration rate $=60 \%$ (Lou and Ulgiati 2013; Gao et al. 2007);

Gibbs free energy of water $=4.94 \times 10^{3} \mathrm{~J} / \mathrm{kg}$. Energy $=($ area $) \times($ rainfall $) \times($ evapotranspiration rate $) \times$ $($ water density $) \times($ Gibbs free energy of water $)=\left(3.18 \mathrm{E} 05 \mathrm{~m}^{2}\right) \times(0.68 \mathrm{~m} / \mathrm{yr}) \times(60 \%) \times\left(1 \mathrm{E} 03 \mathrm{~kg} / \mathrm{m}^{3}\right)$ $\times(4.94 \mathrm{E} 03 \mathrm{~J} / \mathrm{kg})=6.41 \mathrm{E} 11 \mathrm{~J} /$ year. UEV $=2.35 \mathrm{E}+04 \mathrm{sej} / \mathrm{J}(\mathrm{Jae}$ and William 2017).

Emergy of one year $=6.41 \mathrm{E}+11 \mathrm{~J} / \mathrm{yr} \times 1 \mathrm{yr} \times 2.35 \mathrm{E}+04 \mathrm{sej} / \mathrm{J}=1.51 \mathrm{E}+16 \mathrm{sej}$.

(3) Rain (geopotential energy) calculation: Area of Scenario A system $=3.18 \mathrm{E}+05 \mathrm{~m}^{2}$;

Rainfall (annual average, $n=5$ ) $=0.68 \mathrm{~m} /$ year (Brown and Bardi 2001);

Average elevation $=316 \mathrm{~m}$ (Wu et al. 2013); water density $=1.00 \mathrm{E}+03 \mathrm{~kg} / \mathrm{m}^{3}$;

Runoff rate $=40.00 \%$ (Lou and Ulgiati 2013). Energy $=($ area $) \times($ rainfall $)$

$\times($ runoff rate $) \times($ water density $) \times($ average elevation $) \times($ gravity $)$

$=\left(3.18 \mathrm{E}+05 \mathrm{~m}^{2}\right) \times(0.71 \mathrm{~m} / \mathrm{yr}) \times(40 \%) \times\left(1 \mathrm{E} 03 \mathrm{~kg} / \mathrm{m}^{3}\right) \times(316 \mathrm{~m}) \times\left(9.8 \mathrm{~kg} / \mathrm{m}^{2}\right)$

$=2.80 \mathrm{E}+11 \mathrm{~J} / \mathrm{yr}$. UEV $=2.79 \mathrm{E}+04 \mathrm{sej} / \mathrm{J}$ (Brown and Bardi 2001).

Emergy of one year $=2.80 \mathrm{E}+11 \mathrm{~J} / \mathrm{yr} \times 1 \mathrm{yr} \times 2.79 \mathrm{E}+04 \mathrm{sej} / \mathrm{J}=7.81 \mathrm{E}+15 \mathrm{sej}$

(4) Wind energy calculation : Area of Scenario A system $=3.18 \mathrm{E}+05 \mathrm{~m}^{2}$; Air density $=1.29 \mathrm{~kg} / \mathrm{m}^{3}$;

Wind velocity (annual average, $n=2$ ) $=3.25 \mathrm{~m} / \mathrm{s}$ (Wu et al. 2013); Velocity of geostrophic wind $=3.25 \mathrm{~m} / \mathrm{s}$ (surface winds are considered as 0.6 of geostrophic wind (China Meteorological

Administration, 2015); Drag coefficient $=1.00 \times 10^{-3}$ (Miller 1964). Energy $=($ area)

$\times($ air density $) \times($ drag coefficient $) \times(\text { velocity of geostrophic wind })^{3}=\left(3.18 \mathrm{E}+05 \mathrm{~m}^{2}\right)$

$\times\left(1.29 \mathrm{~kg} / \mathrm{m}^{3}\right) \times\left(1.00 \times 10^{-3}\right) \times(3.25 \mathrm{~m} / \mathrm{s})^{3} \times(3.15 \mathrm{E}+07 \mathrm{~s} /$ year $)=4.43 \mathrm{E}+11 \mathrm{~J} / \mathrm{yr}$.

$\mathrm{UEV}=1.90 \mathrm{E} 03 \mathrm{sej} / \mathrm{J}$ (Hwang and William 2015).

Emergy of one year $=4.43 \mathrm{E} 11 \mathrm{~J} / \mathrm{yr} \times 1 \mathrm{yr} \times 1.9 \mathrm{E} 03 \mathrm{sej} / \mathrm{J}=8.42 \mathrm{E} 14 \mathrm{sej}$ 
(5) Geothermal heat calculation : Area of Scenario A system $=3.18 E+05 \mathrm{~m}^{2}$;

Heat flow $($ average $)=3.50 \times 10^{-2} \mathrm{~J} / \mathrm{m}^{2} / \mathrm{s}$. Energy $=($ area $) \times($ heat flow $)$

$=\left(3.18 E+05 \mathrm{~m}^{2}\right) \times\left(3.50 E-02 \mathrm{~J} / \mathrm{m}^{2} / \mathrm{s}\right) \times(3.15 E+07 \mathrm{~s} /$ year $)=3.51 E+11 \mathrm{~J} / \mathrm{yr}$.

$\mathrm{UEV}=3.44 E+04 \mathrm{sej} / \mathrm{J}$ (Brown and Bardi 2001).

Emergy of one year $=3.51 \mathrm{E}+11 \mathrm{~J} / \mathrm{yr} \times 1 \mathrm{yr} \times 3.44 E+04 \mathrm{sej} / \mathrm{J}=1.27 E+14$ sej

2. Input resources

The amount emergy:

Untreated sludge $=1.21 \mathrm{E} 07 \times 1.45 \mathrm{E} 11=1.75 \mathrm{E} 18 \mathrm{sej}$;

Flocculant $=3.41 \mathrm{E} 02 \times 6.38 \mathrm{E} 14=2.18 \mathrm{E} 17 \mathrm{sej}$;

3. Economic investment

The emergy calculations: Invest ment $=3.74 \mathrm{E} 05 \times 1.49 \mathrm{E} 11=5.57 \mathrm{E} 16 \mathrm{sej}$;

Operating cost $=1.98 \mathrm{E} 05 \times 1.62 \mathrm{E} 12=3.21 \mathrm{E} 17 \mathrm{sej}$; Landfill cost $=6.36 \mathrm{E} 04 \times 1.62 \mathrm{E} 12=1.03 \mathrm{E} 17 \mathrm{sej}$;

4. Labor and services

The amount emergy of labor and services:

Labor and services $=3.02 \mathrm{E} 05 \times 1.14 \mathrm{E} 10=3.44 \mathrm{E} 15 \mathrm{sej}$; Governmental subsidies $=4.57 \mathrm{E} 04 \times 1.62 \mathrm{E} 12=7.40 \mathrm{E} 16 \mathrm{sej}$.

5. Energy

The amount emergy of energy:

Electricity $($ Plant usage $)=1.62 \mathrm{E} 12 \times 4.50 \mathrm{E} 05=7.29 \mathrm{E} 17 \mathrm{~s}$ ej; Coal (fuel in turbine) $=5.43 \mathrm{E} 10 \times 1.11 \mathrm{E} 05=6.03 \mathrm{E} 15 \mathrm{sej}$.

6. Transportation

Transportation emergy of annual sludge treatment

$=(55.8$ tons $\times 10 \mathrm{~km} \times 365 \mathrm{~d}) \times(7.61 E+11)$

$=1.55 E+16 \mathrm{sej}$

7. Exhaust gas emissions emergy of Scenario A

(1) The economic loss emergy:

$$
\begin{aligned}
L_{\text {Dust }}= & \sum W_{\mathrm{i}} \times \mathrm{DALY}_{i} \times \alpha=(35 E-09) \times(3.75 E-04) \\
& \times(1.68 E+16) \times 365 \times(2.5 E+05)=2.01 E+13 \mathrm{sej} \\
L_{\mathrm{SO}_{2}}= & \sum W_{i} \times \mathrm{DALY}_{i} \times \alpha \\
= & (50 E-09) \times(5.46 E-05) \times(1.68 E+16) \\
& \times 365 \times(2.5 E+05)=4.18 E+13 \mathrm{sej} \\
L_{\mathrm{NO}_{X}}= & \sum W_{i} \times \mathrm{DALY}_{i} \times \alpha=(80 E-09) \\
& \times(8.87 E-04) \times(1.68 E+16) \\
& \times 365 \times(2.5 E+05)=1.09 E+14 \mathrm{sej}
\end{aligned}
$$$$
L_{\mathrm{CO}_{2}}=\sum W_{i} \times \mathrm{DALY}_{i} \times \alpha=(200 E-09) \times(5.46 E-05)
$$$$
\times(1.68 E+16) \times 365 \times(2.5 E+05)=1.67 E+14 \mathrm{sej}
$$

$$
\begin{aligned}
L_{\mathrm{N}_{2} \mathrm{O}}= & \sum W_{i} \times \mathrm{DALY}_{i} \times \alpha=(80 E-09) \times(8.87 E-04) \\
& \times(1.68 E+16) \times 365 \times(2.5 E+05)=1.09 E+14 \mathrm{sej}
\end{aligned}
$$

(2) The ecological services emergy:

$$
\begin{aligned}
M_{\text {Dust }}= & c \times\left(\frac{U_{i} \times 10^{6}}{s_{i}}\right)=1.23 \times\left[\frac{(35 E-09) \times(1.0 E+06)}{0.08}\right] \\
& \times(2.5 E+05) \times 365=4.93 E+07 \mathrm{~kg} / \mathrm{a} \\
M_{\mathrm{SO}_{2}}= & c \times\left(\frac{U_{i} \times 10^{6}}{s_{i}}\right)=1.23 \times\left[\frac{(50 E-09) \times(1.0 E+06)}{0.02}\right] \\
& \times(2.5 E+05) \times 365=2.81 E+08 \mathrm{~kg} / \mathrm{a}
\end{aligned}
$$

$$
\begin{aligned}
M_{\mathrm{NO}_{\mathrm{X}}}= & c \times\left(\frac{U_{i} \times 10^{6}}{s_{i}}\right)=1.23 \times\left[\frac{(80 E-09) \times(1.0 E+06)}{0.05}\right] \\
& \times(2.5 E+05) \times 365=1.79 E+08 \mathrm{~kg} / \mathrm{a}
\end{aligned}
$$

$$
\begin{aligned}
M_{\mathrm{CO}_{2}}= & c \times\left(\frac{U_{i} \times 10^{6}}{s_{i}}\right)=1.23 \times\left[\frac{(200 E-09) \times(1.0 E+06)}{0.02}\right] \\
& \times(2.5 E+05) \times 365=1.12 E+09 \mathrm{~kg} / \mathrm{a}
\end{aligned}
$$

$$
\begin{aligned}
M_{\mathrm{N}_{2} \mathrm{O}}= & c \times\left(\frac{U_{i} \times 10^{6}}{s_{i}}\right)=1.23 \times\left[\frac{(80 E-09) \times(1.0 E+06)}{0.05}\right] \\
& \times(2.5 E+05) \times 365=1.79 E+08 \mathrm{~kg} / \mathrm{a}
\end{aligned}
$$

$$
\begin{aligned}
R_{\text {Dust }}= & 0.5 \times M_{\text {Dust }} \times v^{2} \times T_{w}=0.5 \times(4.93 E+07) \\
& \times 3.25^{2} \times(1.86 E+03)=4.84 E+12 \mathrm{sej}
\end{aligned}
$$

$$
\begin{aligned}
R_{\mathrm{SO}_{2}}= & 0.5 \times M_{\mathrm{SO}_{2}} \times v^{2} \times T_{w}=0.5 \times(2.81 E+08) \\
& \times 3.25^{2} \times(1.86 E+03)=2.76 E+12 \mathrm{sej} \\
R_{\mathrm{NO}_{X}}= & 0.5 \times M_{\mathrm{NO}_{X}} \times v^{2} \times T_{w}=0.5 \times(1.79 E+08) \\
& \times 3.25^{2} \times(1.86 E+03)=1.76 E+12 \mathrm{sej}
\end{aligned}
$$

$$
\begin{aligned}
R_{\mathrm{CO}_{2}}= & 0.5 \times M_{\mathrm{CO}_{2}} \times v^{2} \times T_{w}=0.5 \times(1.12 E+09) \\
& \times 3.25^{2} \times(1.86 E+03)=1.10 E+13 \mathrm{sej}
\end{aligned}
$$




$$
\begin{aligned}
R_{\mathrm{N}_{2} \mathrm{O}}= & 0.5 \times M_{\mathrm{N}_{2} \mathrm{O}} \times v^{2} \times T_{w}=0.5 \times(1.79 E+08) \\
& \times 3.25^{2} \times(1.86 E+03)=1.76 E+12 \mathrm{sej}
\end{aligned}
$$

(3) The sum:

Emergy $_{\text {dust }}=(2.01 E+13)+(4.84 E+12)=2.49 E+13$ sej

Emergy $_{\mathrm{SO}_{2}}=(4.18 E+13)+(2.76 E+12)=4.46 E+13$ sej
Emergy $_{\mathrm{NO}_{X}}=(1.09 E+14)+(1.76 E+12)=1.11 E+14$ sej

Emergy $_{\mathrm{CO}_{2}}=(1.67 E+14)+(1.10 E+13)=1.78 E+14$ sej

Emergy $_{\mathrm{NO}_{X}}=(1.09 E+14)+(1.76 E+12)=1.11 E+14$ sej

\section{Appendix 2 (Table 6)}

1. Renewable Energy calculation:

(1) Solar energy calculation : Area of Scenario A system $=3.18 \mathrm{E}+05 \mathrm{~m}^{2}$;

Insolation (Hubei Province, China) $=5.43 \times 109 \mathrm{~J} / \mathrm{m}^{2} / \mathrm{yr}$; Albedo $=0.30($ Lou and Ulgiati 2013) .

Energy $=($ solation $) \times(1-$ albedo $) \times($ area $)=\left(5.43 \times 109 \mathrm{~J} / \mathrm{m}^{2} / \mathrm{yr}\right) \times(1-0.30) \times\left(3.18 \mathrm{E}+05 \mathrm{~m}^{2}\right)$

$=1.32 \mathrm{E}+08 \mathrm{~J} / \mathrm{yr} . \mathrm{UEV}=1.00 \mathrm{sej} / \mathrm{J}$ by definition. Emergy $=1.32 \mathrm{E} 08 \mathrm{~J} / \mathrm{yr} \times 1 \mathrm{yr} \times 1 \mathrm{sej} / \mathrm{J}=1.32 \mathrm{E} 08 \mathrm{sej}$

(2) Rain(chemical potential energy) calculation : Area of Scenario A system $=3.18 \mathrm{E}+05 \mathrm{~m}^{2}$;

Rainfall (annual average, $n=5$ ) $=0.68 \mathrm{~m} /$ year (Jiangsu Provincial Bureau of Statistics, China, $2012-2016$.);

Water density $=1.00 \mathrm{~kg} / \mathrm{m}^{3}$; Evapotranspiration rate $=60 \%$ (Lou and Ulgiati 2013; Gao et al. 2007);

Gibbs free energy of water $=4.94 \times 10^{3} \mathrm{~J} / \mathrm{kg}$. Energy $=($ area $) \times($ rainfall $) \times($ evapotranspiration rate $)$

$\times($ water density $) \times($ Gibbs free energy of water $)=\left(3.18 \mathrm{E} 05 \mathrm{~m}^{2}\right) \times(0.68 \mathrm{~m} / \mathrm{yr}) \times(60 \%) \times\left(1 \mathrm{E} 03 \mathrm{~kg} / \mathrm{m}^{3}\right)$

$\times(4.94 \mathrm{E} 03 \mathrm{~J} / \mathrm{kg})=6.41 \mathrm{E} 11 \mathrm{~J} /$ year. UEV $=2.35 \mathrm{E}+04 \mathrm{sej} / \mathrm{J}(\mathrm{Jae}$ and William 2017).

Emergy of one year $=6.41 \mathrm{E}+11 \mathrm{~J} / \mathrm{yr} \times 1 \mathrm{yr} \times 2.35 \mathrm{E}+04 \mathrm{sej} / \mathrm{J}=1.51 \mathrm{E}+16 \mathrm{sej}$.

(3) Rain (geopotential energy) calculation: Area of Scenario A system $=3.18 E+05 \mathrm{~m}^{2}$;

Rainfall (annual average, $n=5$ ) $=0.68 \mathrm{~m} /$ year (Brown and Bardi 2001);

Average elevation $=316 \mathrm{~m}$ (Wu et al. 2013); water density $=1.00 E+03 \mathrm{~kg} / \mathrm{m}^{3}$;

Runoff rate $=40.00 \%$ (Lou and Ulgiati 2013). Energy $=($ area $) \times($ rainfall $)$

$\times($ runoff rate $) \times($ water density $) \times($ average elevation $) \times($ gravity $)$

$=\left(3.18 E+05 \mathrm{~m}^{2}\right) \times(0.71 \mathrm{~m} / \mathrm{yr}) \times(40 \%) \times\left(1 \mathrm{E} 03 \mathrm{~kg} / \mathrm{m}^{3}\right) \times(316 \mathrm{~m}) \times\left(9.8 \mathrm{~kg} / \mathrm{m}^{2}\right)$

$=2.80 E+11 \mathrm{~J} / \mathrm{yr}$. UEV $=2.79 E+04 \mathrm{sej} / \mathrm{J}($ Brown and Bardi 2001).

Emergy of one year $=2.80 E+11 \mathrm{~J} / \mathrm{yr} \times 1 \mathrm{yr} \times 2.79 E+04 \mathrm{sej} / \mathrm{J}=7.81 E+15 \mathrm{sej}$

(4) Wind energy calculation: Area of Scenario A system $=3.18 E+05 \mathrm{~m}^{2}$; Air density $=1.29 \mathrm{~kg} / \mathrm{m}^{3}$;

Wind velocity (annual average, $n=2$ ) $=3.25 \mathrm{~m} / \mathrm{s}$ (Wu et al. 2013); Velocity of geostrophic wind

$=3.25 \mathrm{~m} / \mathrm{s}$ (surface winds are considered as 0.6 of geostrophic wind (China Meteorological

Administration 2015); Drag coefficient $=1.00 \times 10^{-3}$ (Miller 1964). Energy $=($ area $) \times$

(air density) $\times($ drag coefficient $) \times(\text { velocity of geostrophic wind })^{3}=\left(3.18 E+05 \mathrm{~m}^{2}\right)$

$\times\left(1.29 \mathrm{~kg} / \mathrm{m}^{3}\right) \times\left(1.00 \times 10^{-3}\right) \times(3.25 \mathrm{~m} / \mathrm{s})^{3} \times(3.15 E+07 \mathrm{~s} /$ year $)=4.43 E+11 \mathrm{~J} / \mathrm{yr}$.

$\mathrm{UEV}=1.90 \mathrm{E} 03 \mathrm{sej} / \mathrm{J}$ (Hwang and William 2015).

Emergy of one year $=4.43 \mathrm{E} 11 \mathrm{~J} / \mathrm{yr} \times 1 \mathrm{yr} \times 1.9 \mathrm{E} 03 \mathrm{sej} / \mathrm{J}=8.42 \mathrm{E} 14 \mathrm{sej}$ 
(5) Geothermal heat calculation: Area of Scenario A system $=3.18 E+05 \mathrm{~m}^{2}$;

Heat flow (average) $=3.50 \times 10^{-2} \mathrm{~J} / \mathrm{m}^{2} / \mathrm{s}$. Energy $=($ area $) \times($ heat flow $)$

$=\left(3.18 E+05 \mathrm{~m}^{2}\right) \times\left(3.50 E-02 \mathrm{~J} / \mathrm{m}^{2} / \mathrm{s}\right) \times(3.15 E+07 \mathrm{~s} /$ year $)=3.51 E+11 \mathrm{~J} / \mathrm{yr}$.

$\mathrm{UEV}=3.44 E+04 \mathrm{sej} / \mathrm{J}$ (Brown and Bardi 2001).

Emergy of one year $=3.51 E+11 \mathrm{~J} / \mathrm{yr} \times 1 \mathrm{yr} \times 3.44 E+04 \mathrm{sej} / \mathrm{J}=1.27 E+14 \mathrm{sej}$

2. Non-renewable resources:

The amount emergy: Cement $=5.44 \mathrm{E} 05 \times 1.93 \mathrm{E} 12=1.0$ $5 \mathrm{E} 18 \mathrm{sej}$;

Steel $\quad$ slag $=2.83 \mathrm{E} 05 \times 2.75 \mathrm{E} 12=7.78 \mathrm{E} 17 \mathrm{sej} ;$ Limestone $=1.31 \mathrm{E} 03 \times 1.27 \mathrm{E} 12=1.66 \mathrm{E} 15 \mathrm{sej}$;

Gravel $=2.03 \mathrm{E} 05 \times 1.42 \mathrm{E} 12=2.28 \mathrm{E} 17 \mathrm{sej} ;$ Tap water $=1$ $.45 \mathrm{E} 04 \times 2.56 \mathrm{E} 12=3.71 \mathrm{E} 16 \mathrm{sej}$.

3. Input resources

The amount emergy:

Untreated sludge $=1.21 \mathrm{E} 07 \times 1.45 \mathrm{E} 11=1.75 \mathrm{E} 18 \mathrm{sej}$; Flocculant $=3.41 \mathrm{E} 02 \times 6.38 \mathrm{E} 14=2.18 \mathrm{E} 17 \mathrm{sej}$;

4. Economic investment

The emergy calculations: Invest ment $=3.74 \mathrm{E} 05 \times 1.49 \mathrm{E} 11=5.57 \mathrm{E} 16 \mathrm{sej}$;

Operating cost $=1.98 \mathrm{E} 05 \times 1.62 \mathrm{E} 12=3.21 \mathrm{E} 17 \mathrm{sej} ;$ Landfill cost $=6.36 \mathrm{E} 04 \times 1.62 \mathrm{E} 12=1.03 \mathrm{E} 17 \mathrm{sej}$;

5 . Labor and services

The amount emergy of labor and services:

Labor and services $=3.02 \mathrm{E} 05 \times 1.14 \mathrm{E} 10=3.44 \mathrm{E} 15 \mathrm{sej}$; Governmental subsidies $=4.57 \mathrm{E} 04 \times 1.62 \mathrm{E} 12=7.40 \mathrm{E} 16$ sej.

6. Energy

The amount emergy of energy:

Electricity $($ Plant usage $)=1.62 \mathrm{E} 12 \times 4.50 \mathrm{E} 05=7.29 \mathrm{E} 17 \mathrm{~s}$ ej; Coal (fuel in turbine) $=5.43 \mathrm{E} 10 \times 1.11 \mathrm{E} 05=6.03 \mathrm{E} 15 \mathrm{sej}$.

7. Transportation

Transportation emergy of annual sludge treatment

$=(55.8$ tons $\times 10 \mathrm{~km} \times 365 \mathrm{~d}) \times(7.61 E+11)=1.55 E+16 s e j$

8. All inputs of Scenario B

(1) Exhaust gas emissions emergy of Scenario B.

1) The economic loss emergy:

$$
\begin{aligned}
L_{\text {Dust }}= & \sum W_{i} \times \mathrm{DALY}_{i} \times \alpha=(35 E-09) \times(3.75 E-04) \\
& \times(1.68 E+16) \times 365 \times(2.5 E+05)=2.01 E+13 \mathrm{sej} \\
L_{\mathrm{SO}_{2}}= & \sum W_{i} \times \mathrm{DALY}_{i} \times \alpha=(50 E-09) \times(5.46 E-05) \\
& \times(1.68 E+16) \times 365 \times(2.5 E+05)=4.18 E+13 \mathrm{sej} \\
L_{\mathrm{NO}_{X}}= & \sum W_{i} \times \mathrm{DALY}_{i} \times \alpha=(80 E-09) \times(8.87 E-04) \\
& \times(1.68 E+16) \times 365 \times(2.5 E+05)=1.09 E+14 \mathrm{sej}
\end{aligned}
$$

$$
\begin{aligned}
L_{\mathrm{CO}_{2}}= & \sum W_{i} \times \mathrm{DALY}_{i} \times \alpha=(200 E-09) \times(5.46 E-05) \\
& \times(1.68 E+16) \times 365 \times(2.5 E+05)=1.67 E+14 \mathrm{sej} \\
L_{\mathrm{N}_{2} \mathrm{O}}= & \sum W_{i} \times \mathrm{DALY}_{i} \times \alpha=(80 E-09) \times(8.87 E-04) \\
& \times(1.68 E+16) \times 365 \times(2.5 E+05)=1.09 E+14 \mathrm{sej}
\end{aligned}
$$

(2) The ecological services emergy:

$$
\begin{aligned}
M_{\text {Dust }}= & c \times\left(\frac{U_{i} \times 10^{6}}{s_{i}}\right)=1.23 \times\left[\frac{(35 E-09) \times(1.0 E+06)}{0.08}\right] \\
& \times(2.5 E+05) \times 365=4.93 E+07 \mathrm{~kg} / \mathrm{a}
\end{aligned}
$$

$$
\begin{aligned}
M_{\mathrm{SO}_{2}}= & c \times\left(\frac{U_{i} \times 10^{6}}{s_{i}}\right)=1.23 \times\left[\frac{(50 E-09) \times(1.0 E+06)}{0.02}\right] \\
& \times(2.5 E+05) \times 365=2.81 E+08 \mathrm{~kg} / \mathrm{a}
\end{aligned}
$$

$$
\begin{aligned}
M_{\mathrm{NO}_{\mathrm{X}}}= & c \times\left(\frac{U_{i} \times 10^{6}}{s_{i}}\right)=1.23 \times\left[\frac{(80 E-09) \times(1.0 E+06)}{0.05}\right] \\
& \times(2.5 E+05) \times 365=1.79 E+08 \mathrm{~kg} / \mathrm{a}
\end{aligned}
$$

$$
\begin{aligned}
M_{\mathrm{CO}_{2}}= & c \times\left(\frac{U_{i} \times 10^{6}}{s_{i}}\right)=1.23 \times\left[\frac{(200 E-09) \times(1.0 E+06)}{0.02}\right] \\
& \times(2.5 E+05) \times 365=1.12 E+09 \mathrm{~kg} / \mathrm{a}
\end{aligned}
$$

$$
\begin{aligned}
M_{\mathrm{N}_{2} \mathrm{O}}= & \mathrm{c} \times\left(\frac{U_{i} \times 10^{6}}{s_{i}}\right)=1.23 \times\left[\frac{(80 E-09) \times(1.0 E+06)}{0.05}\right] \\
& \times(2.5 E+05) \times 365=1.79 E+08 \mathrm{~kg} / \mathrm{a}
\end{aligned}
$$

$$
\begin{aligned}
R_{\text {Dust }}= & 0.5 \times M_{\text {Dust }} \times v^{2} \times T_{w}=0.5 \times(4.93 E+07) \\
& \times 3.25^{2} \times(1.86 E+03)=4.84 E+12 \mathrm{sej}
\end{aligned}
$$

$$
R_{\mathrm{SO}_{2}}=0.5 \times M_{\mathrm{SO}_{2}} \times v^{2} \times T_{w}=0.5 \times(2.81 E+08)
$$$$
\times 3.25^{2} \times(1.86 E+03)=2.76 E+12 \mathrm{sej}
$$

$$
R_{\mathrm{NO}_{X}}=0.5 \times M_{\mathrm{NO}_{X}} \times v^{2} \times T_{w}=0.5 \times(1.79 E+08)
$$$$
\times 3.25^{2} \times(1.86 E+03)=1.76 E+12 \text { sej }
$$

$$
R_{\mathrm{CO}_{2}}=0.5 \times M_{\mathrm{CO}_{2}} \times v^{2} \times T_{w}=0.5 \times(1.12 E+09)
$$$$
\times 3.25^{2} \times(1.86 E+03)=1.10 E+13 \mathrm{sej}
$$ 


$$
\begin{aligned}
R_{\mathrm{N}_{2} \mathrm{O}}= & 0.5 \times M_{\mathrm{N}_{2} \mathrm{O}} \times v^{2} \times T_{w}=0.5 \times(1.79 E+08) \\
& \times 3.25^{2} \times(1.86 E+03)=1.76 E+12 \mathrm{sej}
\end{aligned}
$$

(3) The sum:

Emergy $_{\text {dust }}=(2.01 E+13)+(4.84 E+12)=2.49 E+13$ sej

$$
\text { Emergy }_{\mathrm{SO}_{2}}=(4.18 E+13)+(2.76 E+12)=4.46 E+13 \text { sej }
$$$$
\text { Emergy }_{\mathrm{NO}_{X}}=(1.09 E+14)+(1.76 E+12)=1.11 E+14 \text { sej }
$$$$
\text { Emergy }_{\mathrm{CO}_{2}}=(1.67 E+14)+(1.10 E+13)=1.78 E+14 \mathrm{sej}
$$

Emergy $_{\mathrm{NO}_{X}}=(1.09 E+14)+(1.76 E+12)=1.11 E+14$ sej

(2) The power output emergy of Scenario B: Electricity output $=1.62 \mathrm{E} 12 \times 4.50 \mathrm{E} 05=7.29 \mathrm{E} 17 \mathrm{sej}$.

(3) Products' economic benefit (brick plant) emergy of Scenario B: $=1.62 \mathrm{E} 12 \times 3.97 \mathrm{E} 05=6.43 \mathrm{E} 17 \mathrm{sej}$.

Acknowledgements The work described in this paper was supported by the Postgraduate Research and Practice Innovation Program of Jiangsu Province (KYCX18_0104).

Funding The authors received no specific funding for this work.

\section{Declarations}

Conflict of interest The authors declare that we have no conflict of interest.

Open Access This article is licensed under a Creative Commons Attribution 4.0 International License, which permits use, sharing, adaptation, distribution and reproduction in any medium or format, as long as you give appropriate credit to the original author(s) and the source, provide a link to the Creative Commons licence, and indicate if changes were made. The images or other third party material in this article are included in the article's Creative Commons licence, unless indicated otherwise in a credit line to the material. If material is not included in the article's Creative Commons licence and your intended use is not permitted by statutory regulation or exceeds the permitted use, you will need to obtain permission directly from the copyright holder. To view a copy of this licence, visit http://creativecommons.org/licenses/by/4.0/.

\section{References}

Agata JT, Wydro U, Serra-Majem L, Butarewicz A, Wołejko E (2019) The comparison of selected types of municipal sewage sludge filtrates toxicity in different biological models: from bacterial strains to mammalian cells. Prelimin Study Water 11(11):2353

Bakshi BR (2002) A thermodynamic framework for ecologically conscious process systems engineering. Comput Chem Eng 26:269-282

Bo L, Serigo U (2013) Identifying the environmental support and constraints to the Chinese economic growth - an application of the emergy accounting method. Energy Policy 55:217-233
Bo M, Liu L, Zhao Y, Zhang C, Hu Z, Leng P (2019) Evaluation of the environmental and plant growth effectiveness of a new substrate consisting of municipal sludge and fly ash. Waste Manag 99:163-171

Bradon K, Tilley DR (2016) An emergy-based treatment sustainability index for evaluating waste treatment systems. J Clean Prod 112:4485-4496

Brown MT, Ulgiati S (2010) Updated evaluation of exergy and emergy driving the geobiosphere: a review and refinement of the emergy baseline. Ecol Model 221:2501-2508

Brown MT, Ulgiati S (2016) Assessing the global environmental sources drivingthe geobiosphere: a revised emergy baseline. Ecol Model 339:126-132

Brown MT, Raugei M, Ulgiati S (2012) On boundaries and 'investments' in emergy synthesis and LCA: a case study on thermal versus photovoltaicelectricity. Ecol Indic 15:227-235

Brown MT, Bardi E (2001) Handbook of emergy evaluation: a compendium of data for emergy computation in a series of folios, Folio. \#3. Center for Environmental Policy, University of Florida, USA

Campbell DE (1998) Emergy analysis of human carrying capacity and regional sustainability: an example using the State of Maine. Environ Monit Assess 51:531-569

Cao C, Feng X (2007) Distribution of emergy indices and its application. Energy Fuels 21:1717-1723

Cassio HAJ, de Lima Brossi MJ, de Lima Brossi MJ, Monteiro RT, Cardoso PHS, da Silva Mandu T, Nogueira TAR, Capra GF (2019) Effects of sewage sludge application on unfertile tropical soils evaluated by multiple approaches: a field experiment in a commercial Eucalyptus plantation. Sci Total Environ 655(2019):1457-1467

China Environmental Statistics Annual Report (2015) http://www.mee. gov.cn/hjzl/sthjzk/sthjtjnb/. Accessed Jan 2020

Choudri BS, Charabi Y (2019) Health effects associated with wastewater treatment, reuse, and disposal. Water Environ Res 91:976-983

CMA, China Meteorological Administration, 2015

Discharge standard of pollutants for municipal wastewater treatment plant, GB 18918-2002

Ferrans L, Tamara A, Müller A, Hiroshan H, Christina D, Serena C (2020) Selecting sustainable sewage sludge reuse options through a systematic assessment framework: methodology and case study in Latin America. J Clean Prod 242:118389

Gao G, Chen DL, Xu CY, Simelton E (2007) Trend of estimated actual evapotranspiration over China during 1960-2002. J Geophys Res 112:D11120

GB 13223-2011, Emission standard of air pollutants for thermal power plants. National mandatory standard in China

Gengyuan L, Yang Z, Chen B, Zhang J, Liu X, Zhang Y, Ulgiati S (2015) Scenarios for sewage sludge reduction and reuse in clinker production towards regional eco-industrial development: a comparative emergybased assessment. J Clean Prod 103:371-383

Gonçalves T, Silva RV, de Brito J, Fernandez JM, Esquinas AR (2020) Mechanical and durability performance of mortars with fine recycled concrete aggregates and reactive magnesium oxide as partial cement replacement. Cem Concrete Compos 105:103420

Hengyu P, Zhang X, Wu J, Zhang Y, Lin L, Yang G, Peng H (2016) Sustainability evaluation of a steel production system in China based on emergy. J Clean Prod 112:1498-1509

Hwang Y, Braham WW (2015) Uncertainty characterization of building emergy analysis (BEmA). Build Environ 92:538-558

Jae Min L, William WB (2017) Building emergy analysis of Manhattan: density parameters forhigh-density and high-rise developments. Ecol Model 363:157-171

Jialin L, Zhang S, Ye M, Huang J, Yang X, Li S, Huang S, Sun S (2020) Improving sewage sludge dewaterability with rapid and cost-effective in-situ generation of $\mathrm{Fe} 2+$ combined with oxidants. Chem Eng J 380:122499 
Jiangsu Provincial Bureau of Statistics, China, 2012-2016. Jiangsu Statistical Yearbook. China Statistics Press, Beijing

Johanna B, Geber U, Rydberg T (2001) Emergy analysis of municipal wastewater treatment and generation of electricity by digestion of sewage sludge. Resour Conserv Recycl 31:293-316

Junxue Z, Ma L (2020) Environmental sustainability assessment of a new sewage treatment plant in china based on infrastructure construction and operation phases emergy analysis. Water 12:484

Kui L, Boqiang L (2019) Research on influencing factors of environmental pollution in China: a spatial econometric analysis. J Clean Prod 206:356-364

Ling S, Chen GQ, Hayat T, Alsaedi A (2014) Systems ecological accounting for wastewater treatment engineering: method, indicator and application. Ecol Ind 47:32-42

Liping W, Yuzhi C, Qifeng L (2019) Fate and distribution of nutrients and heavy metals during hydrothermal carbonization of sewage sludge with implication to land application. J Clean Prod 225:972-983

Liu G, Yang Z, Chen B, Zhang L (2013) Modelling a thermodynamicbased comparative framework for urban sustainability: incorporating economic and ecological losses into emergy analysis. Ecol Model 252:280-287

Lou B, Ulgiati S (2013) Identifying the environmental support and constraints to the Chinese economic growth-an application of the emergy accounting method. Energy Policy 55:217-233

Ludovic G, Franco R, Francesco DV, Roberta G, Stefano M, Giovanni R, Markus S, Michela V (2014) Climate change impacts on hydropower in the Swiss and Italian Alps. Sci Total Environ 493:1211-1221

Luís PA, Nélson M, Joaquim BG (2016) A review of emergy theory, its application and latest developments. Renew Sustain Energy Rev 54:882-888

Marc M, Srinivasan RS, Ries R (2016) Complementary life cycle assessment of wastewater treatment plants: An integrated approach to comprehensive upstream and downstream impact assessments and its extension to building-level wastewater generation. Sustain Cities Soc 23:37-49

Mark TB, Campbell DE, De Vilbiss C, Ulgiati S (2016) The geobiosphere emergy baseline: a synthesis. Ecol Model 339:92-95

Miller BI (1964) A study of the filling of hurricane Donna over land (2000). Monthly Weather Review. U.S. Department of Agriculture 92, pp 389-406

Ministry of Environmental Protection of the People's Republic of China. Ambient air quality standard (GB3095-2012)

Mirko C, Anna R, Claudia Z, Daniela P, Chiara T, Simone S, Giovanni $G$ (2019) Benefits and risks of long-term recycling of pharmaceutical sewage sludge on agricultural soil. Sci Total Environ 695:133762

Nakic D (2018) Environmental evaluation of concrete with sewage sludge ash based on LCA. Sustain Prod Consump 16:193-201

Natalia ACL, Darío GS, Velásquez HI, Ruiz-Mercado GJ (2018) Emergy analysis for the sustainable utilization of biosolids generated in a municipal wastewater treatment plant. J Clean Prod. Author manuscript; available in PMC 2018 September 19

National Economic and Social Development Statistics Report in Shanghai, 2018

Nozela WC, Nozela CFV, Silva FR, Dias DS, Almeida S, Ribeiro CA, Crespi MS (2018) Kinetic study of the energetic reuse from torrefied sewage sludge and urban pruning blends. J Therm Anal Calorim 134:1285-1291

Odum HT (1996) Environmental accounting: emergy and environmental decision making. Wiley, New York

Odum HT (2000) Handbook of emergy evaluation (Folio \#2): emergy of global processes. center for environmental policy environmental engineering sciences Box 116450 University of Florida Gainesville, 32622-6450, pp 17-18
Patrick MM, Rosa B, Hooda PS, Cundy AB, Sohi SP (2019) Driving forces and barriers in the removal of phosphorus from water using crop residue, wood and sewage sludge derived biochars. Sci Total Environ 675:623-631

Peronato G, Rastogi P, Rey E, Andersen M (2018) A toolkit for multi-scale mapping of the solar energy-generation potential of buildings in urban environments under uncertainty. Sol Energy 173:861-874

Raphael RZT, Adisa A (2018) Life cycle costs of advanced treatment techniques for wastewater reuse and resource recovery from sewage sludge. J Clean Prod 204:832-847

Sadegh A, Hamid Z, Fatemeh R, Masoud R, Akram A (2020) The eco-efficiency assessment of wastewater treatment plants in the city of Mashhad using emergy and life cycle analyses. J Clean Prod 249:119327

Sam A, Xin M, Mark B (2019) Holistic analysis of urban water systems in the Greater Cincinnati region: resource use profiles by emergy accounting approach. Water Res 2:100012

Sayed S, Mokhtar ALY, Bálint H (2019) A robust SMES control for enhancing stability of distribution systems fed from intermittent wind power generation. Turk J Electric Eng Comput Sci 27:3883-3898

Shanghai Meteorological Bureau, 2019. http://sh.cma.gov.cn/sh/

Shao L, Chen GQ (2016) Renewability assessment of a production system: based on embodied energy as emergy. Renew Sustain Energy Rev 57:380-392

Shengwen T, Jingtao C, Peigui S, Yang L, Peng Y, Chen E (2019) Current and future hydropower development in Southeast Asia countries (Malaysia, Indonesia, Thailand and Myanmar). Energy Policy 129:239-249

Shuai S, Mu H, Yang F, Zhang Y, Li J (2017) Application of emergy analysis to the sustainability evaluation of municipal wastewater treatment plants. Sustainability 9:8

Taixiu L, Zhang B, Zhimei Z, Qibin L, Jing L, Jun S, Hongguang J (2019) $100 \mathrm{kWe}$ power generation pilot plant with a solar thermochemical process: design, modeling, construction, and testing. Appl Energy 251:113217

Ulgiati S, Brown MT (2002) Quantifying the environmental support for dilutionand abatement of process emissions: the case of electricity production. J Clean Prod 10:335-348

Wei C et al (2016) Life cycle based emergy analysis on China's cement production. J Clean Prod 131:272-279

Wenjun Z, Long C, Lili F (2019) Effectiveness evaluation on thirdparty governance model for environmental pollution in China. Environ Sci Pollut Res 26:17305-17320

Wu MQ, Zhang AD, Kan ZQ, Sun XB, Lin X (2013) Land surface temperature retrieved using MODIS data in Shandong Province. Geoinformatics. In: 21st International conference on IEEE

XiaoHong Z, ShiHuai D, Jun W, Wenju J (2010) A sustainability analysis of a municipal sewage treatment ecosystem based on emergy. Ecol Eng 36:685-696

Xiaohong Z, Ni X, Wenlong W, Wenjie L, Xiangdong Y, Wei S, Jun W, Shihuai D (2018) An emergy evaluation of the sewage sludge treatment system with earthworm compositing technology in Chengdu. China Ecol Eng 110:8-17

Xingyang H, Zhengqi Z, Mengyang M, Ying S, Jin Y, Hongbo T, Yingbin W, Bohumír S (2020) New treatment technology: the use of wet-milling concrete slurry waste to substitute cement. J Clean Prod 242:118347

Xueya L, Lijuan L, Pingsheng L, Zenghui H (2019) Feasible and effective reuse of municipal sludge for vegetation restoration: physiochemical characteristics and microbial diversity. Sci Rep 9:879

Yan Q, Xiaohong Z, Xiangdong Y, Yanfeng L, Jun W, Lili L, Yinlong X, Hui Q, Xiaoyu Y, Yanzong Z (2018) The environmental sustainability evaluation of an urban tap water treatment plant based on emergy. Ecol Ind 94:28-38 
Yanqing W, Xiaohong Z, Wenjie L, Jun W, Xiangdong Y, Wei S, Shihuai D, Yanzong Z, Lili L, Yinlong X, Xiaoyu Y, Hong P (2018) Investigating impact of waste reuse on the sustainability of municipal solid waste (MSW) incineration industry using emergy approach: a case study from Sichuan province. China Waste Manag 77:252-267

Yimin W, Mingzhe Z, Jianxia C, Xuebin W, Yuyu T (2019) Study on the combined operation of a hydro-thermal-wind hybrid power system based on hydro-wind power compensating principles. Energy Convers Manag 194:94-111

Yuchi C, Jingwen S, Hao R, Xian Z, Fangyuan C, Xuli L, Teng W, Haobo H (2020) Adsorption mechanism of lead ions on porous ceramsite prepared by co-combustion ash of sewage sludge and biomass. Sci Total Environ 702:135017
Zhang XH, Jiang WJ, Deng SH, Peng K (2009) Emergy evaluation of the sustainability of Chinese steel production during 1998-2004. J Clean Prod 17:1030-1038

Zhi-Xiang X, Song H, Deng XQ, Zhang YY, Xue-Qin M, Tong SQ, Hu X (2019) Dewatering of sewage sludge via thermal hydrolysis with ammonia-treated Fenton iron sludge as skeleton material. J Hazardous Mater 379:120810

Zhou JB, Jiang MM, Chen B (2009) Emergy evaluations for constructed wetland and conventional wastewater treatment. Commun Nonlinear Sci Numer Simul 14:1781-1789

Publisher's Note Springer Nature remains neutral with regard to jurisdictional claims in published maps and institutional affiliations. 